\title{
The exhumation of the western Greater Caucasus: a thermochronometric study
}

\author{
STEPHEN J. VINCENT*†, ANDREW CARTER $\ddagger$, VLADIMIR A. LAVRISHCHEV $\S$, \\ SAMUEL P. RICE*, TEIMURAZ G. BARABADZE $₫$ \& NIELS HOVIUS $\|$ \\ *CASP, University of Cambridge, 181a Huntingdon Road, Cambridge CB3 0DH, UK \\ $\ddagger$ Research School of Earth Sciences, University and Birkbeck College, London WC1E 6BT, UK \\ $\S$ Kavkazgeols'emka, Ul. Kislovodskaya 203, Yessentuki, Russia \\ GGeorgian Technical University, 77 Kostava Street, 380075, Tbilisi, Georgia \\ ॥Department of Earth Sciences, University of Cambridge, Downing Street, Cambridge CB2 3EQ, UK
}

(Received 25 September 2009; accepted 12 February 2010; first published online 5 May 2010)

\begin{abstract}
This study provides 39 new thermochronometric analyses from the western part of the Greater Caucasus, a region in which existing data are extremely limited and of questionable quality. The new results are consistent with field studies that identify Triassic to Middle Jurassic (Cimmerian) and Oligo-Miocene (Alpine) orogenic erosional events. An inverse relationship between the fission track and depositional ages of Oligo-Miocene sedimentary samples also implies some degree of Eocene erosion of the Greater Caucasus and intermediate sediment storage. Cooling ages and field relationships within the core of the range, west of Mt Elbrus, require $\sim 5 \mathrm{~km}$ of Permo-Triassic exhumation and restrict the overall amount of Cenozoic exhumation to $\sim 2.5 \mathrm{~km}$. Current exhumation rates are typically low, and do not support a Plio-Pleistocene increase in climate-driven denudation. High $\left(\sim 1 \mathrm{~km} \mathrm{Ma}^{-1}\right)$ rates of exhumation are restricted to the southern flank of the range in northwest Georgia. Despite a general lack of significant seismicity within the study region, this exhumation peak is close to the largest instrumentally recorded earthquake in the Caucasus ( $\mathrm{Ms}=7.0$ ). This may suggest that exhumation is associated with the decoupling of the sedimentary succession from its crystalline basement in the southern part of the range and the inversion of the largely Jurassic fill of the Greater Caucasus basin. Rates of exhumation are compatible with this being driven by active shortening. Further sampling and analysis are required to provide a higher-resolution, low-temperature thermochronology of Alpine exhumation, to isolate the drivers for Palaeogene Dziruli Massif cooling and uplift, and to constrain better the extent of the current, localized phase of rapid exhumation.
\end{abstract}

Keywords: exhumation, uplift, fission track, Caucasus, Dziruli Massif.

\section{Introduction}

The Greater Caucasus is Europe's largest mountain belt and yet, in marked contrast to the Alps, Pyrenees and Carpathians, relatively little is known about its evolution. Many modern analytical techniques, such as thermochronology, have barely been attempted within the range despite having been applied with success elsewhere (e.g. Cederbom et al. 2004; Gunnell et al. 2009). This paper presents the results of a thermochronometric study from the western part of the Greater Caucasus. It provides initial insights into the exhumation of the range that, it is hoped, will be built upon by others in this highly complex and politically troubled region.

\section{Regional background}

The western Greater Caucasus is situated at the southern deformed edge of the Scythian Platform (part of Eurasia), north of the eastern Black Sea basin and a series of accreted arcs, oceanic slivers,

†Author for correspondence: stephen.vincent@casp.cam.ac.uk continental fragments and sedimentary basins of the Tethyside orogenic collage (Şengör \& Y1lmaz, 1981; Dixon \& Robertson, 1984; Şengör, 1987; Şengör \& Natal'in, 1996; Fig. 1). It comprises a central core of Gondwana-derived, predominantly Lower to middle Palaeozoic crystalline protolith and middle Palaeozoic island arc and ophiolitic material that were metamorphosed and intruded during their Variscan accretion to the southern margin of Laurasia (Zonenshain, Kuzmin \& Natapov, 1990; Hanel, Gurbanov \& Lippolt, 1992; Hanel et al. 1993; Somin et al. 2006; Somin, Lepekhina \& Konilov, 2007; Zakariadze et al. 2007; Somin, Potapenko \& Smul'skaya, 2009; Treloar et al. 2009; Fig. 2). Mesozoic sediments onlap this crystalline core and record a series of extensional and compressional events that resulted from Tethyan active-margin processes further to the south. Middle to end-Triassic compressional/transpressional events (the early Cimmerian orogeny, sensu Nikishin et al. 2001) were followed by Early Jurassic extension/transtension, which led to the formation of deep sedimentary troughs (the Greater Caucasus Basin) both to the north of the core of the western Greater Caucasus and to the south, between it and similar crystalline basement exposed in 


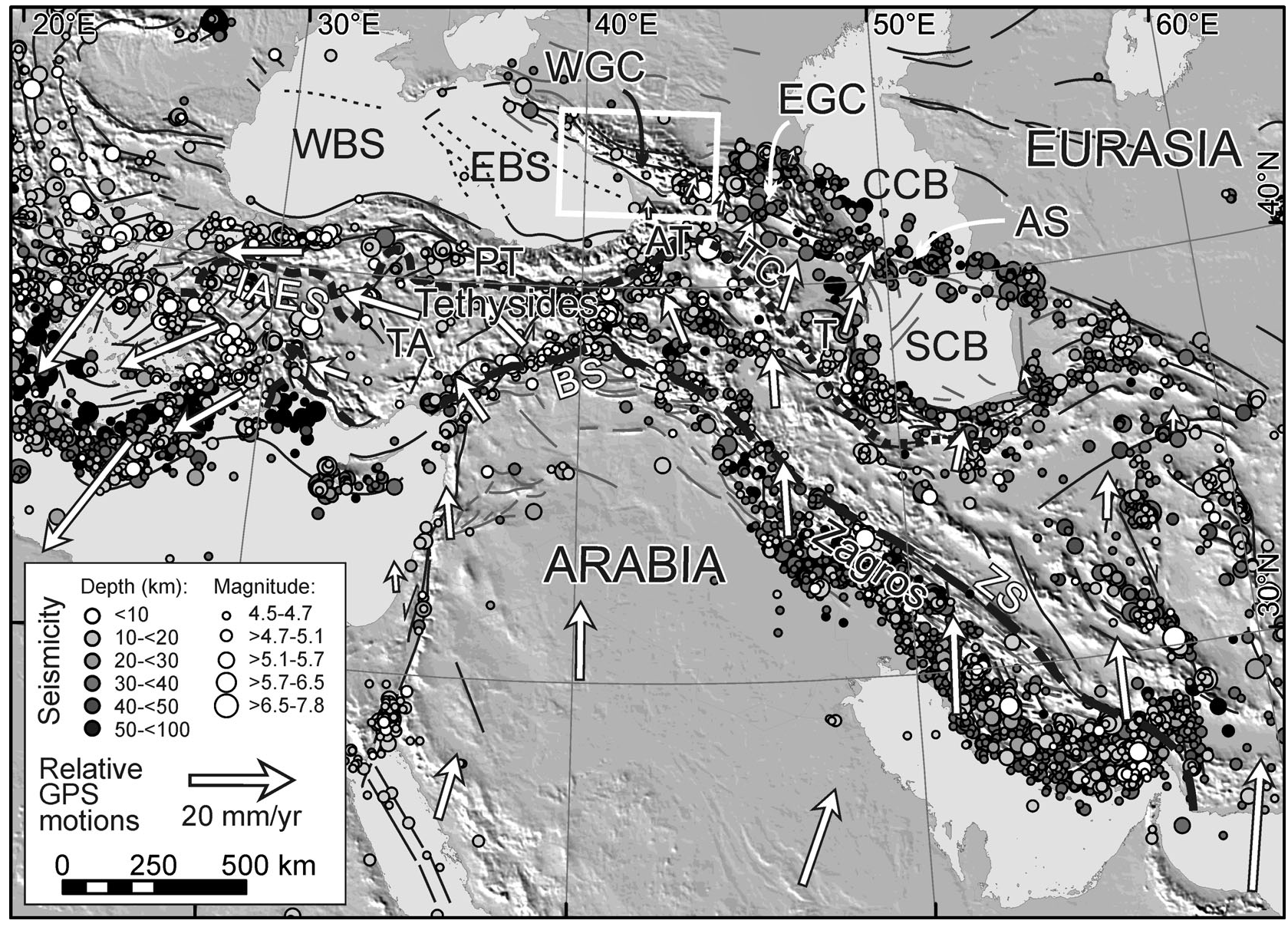

Figure 1. Schematic tectonic map showing the Greater Caucasus at the northern margin of the Arabia-Eurasia collision zone, the current GPS-constrained motion of the region relative to stable Eurasia and the occurrence of instrumentally recorded earthquakes $M \geq 4.5$. Structures are extended from Allen et al. (2003), GPS motions are taken from Reilinger et al. (2006) and the seismicity record from the US National Earthquake Information Center catalogue (1973-June 2009). The study area is highlighted in the box and selected Neotethyan suture zones shown by dashed lines. Abbreviations: AS - Apsheron sill; AT - Adjara-Trialet belt; BS - Bitlis suture; CCB - Central Caspian Basin; EBS - Eastern Black Sea; EGC - eastern Greater Caucasus; IAES - İsmir-Ankara-Erzincan suture; PT - Pontides; SCB - South Caspian Basin; T - Talysh; TA - Taurides-Anatolides; TC - Transcaucasus; WBS - Western Black Sea; WGC - western Greater Caucasus; ZS - Zagros suture. For a colour version of this figure see the online Appendix at http://journals.cambridge.org/geo.

the Dziruli Massif (Nikishin et al. 1998b; Dercourt et al. 2000; Nikishin et al. 2001; Golonka, 2004; Saintot et al. 2006a; Figs 2, 3). Middle Jurassic (middle Cimmerian) deformation led to the partial inversion of these basins before further extension/transtension occurred in Early Cretaceous time.

South of the Greater Caucasus, Late Cretaceous to Early Cenozoic deformation occurred across a large part of the Tethyside orogenic collage. Most notably, the Late Paleocene to Middle Eocene terminal collision of the Pontide-Transcaucasus and TaurideAnatolide regions (along the İzmir-Ankara-Erzincan suture zone; Fig. 1) resulted in the elimination of northern Neotethys (Şengör \& Y1lmaz, 1981; Okay \& Şahintürk, 1997; Yılmaz et al. 1997; Okay \& Tüysüz, 1999; Okay, Tansel \& Tüysüz, 2001; Boztuğ et al. 2004; Rice, Robertson \& Ustaömer, 2006; Robertson, Parlak \& Ustaömer, 2009). This event is marked by a regional unconformity identified both at outcrop and in Black Sea seismic data (Okay \& Şahintürk,
1997; Y1lmaz et al. 1997; Afanasenkov, Nikishin \& Obukhov, 2007; Apaydın et al. 2009; Güney et al. 2009; Khriachtchevskaia, Stovba \& Stephenson, 2010). Early to Middle Eocene post-collisional onlap was associated with widespread, predominantly Middle Eocene, postcollisional volcanism south of the Greater Caucasus (attributed to slab break-off: Genç \& Y1lmaz, 1997; Keskin, Genç \& Tüysüz, 2008; Dilek \& Altunkaynak, 2009). Volcanism was accompanied by transtensional basin formation in the Transcaucasus (the Talysh and Adjara-Trialet basins: Adamia, Lordkipanidze \& Zakariadze, 1977; Nikishin et al. 2001; Vincent et al. 2005). Transtensional stress development and localized sediment thickness variations within Upper Cretaceous to Eocene strata have also been recognized in the western Greater Caucasus (Lavrishchev et al. 2000; Saintot \& Angelier, 2002). However, a predominance of shallow-water, fine-grained, carbonate sedimentary facies suggests that as a whole this region was relatively quiescent. 


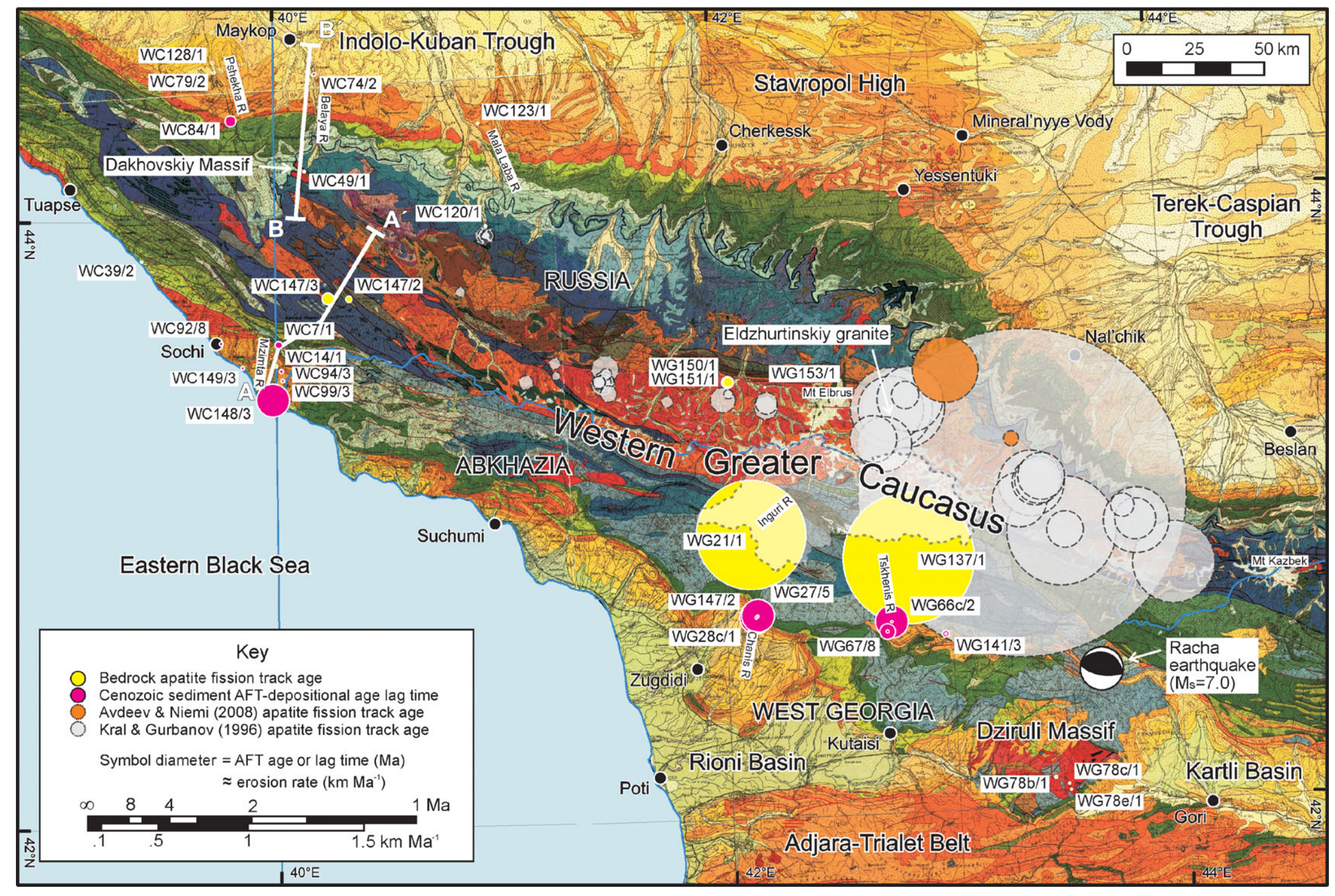

Figure 2. Thermochronometric data summary map for the western Greater Caucasus. Bedrock samples record the thermal history of the sample site, while the Cenozoic sediment samples record the thermal history of their catchment areas within the evolving Caucasus mountain belt. The white transparent region represents the catchment area of the Inguri River upstream of cosmogenic sample site WG21/1 across which an erosion rate equivalent to $\sim 1.1 \mathrm{~km} \mathrm{Ma}^{-1}$ was derived. The fault plane solution for the Racha earthquake is from Triep et al. (1995). Note that the dataset of Král \& Gurbanov (1996) is likely to be inaccurate due to the use of less reliable FT methodologies. The background map is a compilation of Soviet-era geological maps with standard colours: red - crystalline basement; brown-grey - Devonian-Carboniferous; pink-purple - Permo-Triassic; blue - Jurassic; green - Cretaceous; orange - Palaeogene; yellow - Neogene. The relationship between cooling age (basement samples) or cooling and depositional age lag time (sediments) and erosion rate was calculated using AGE2EDOT, assuming an average geothermal gradient of $40{ }^{\circ} \mathrm{C} \mathrm{km}{ }^{-1}$, and is an approximation. For location see Figure 1 


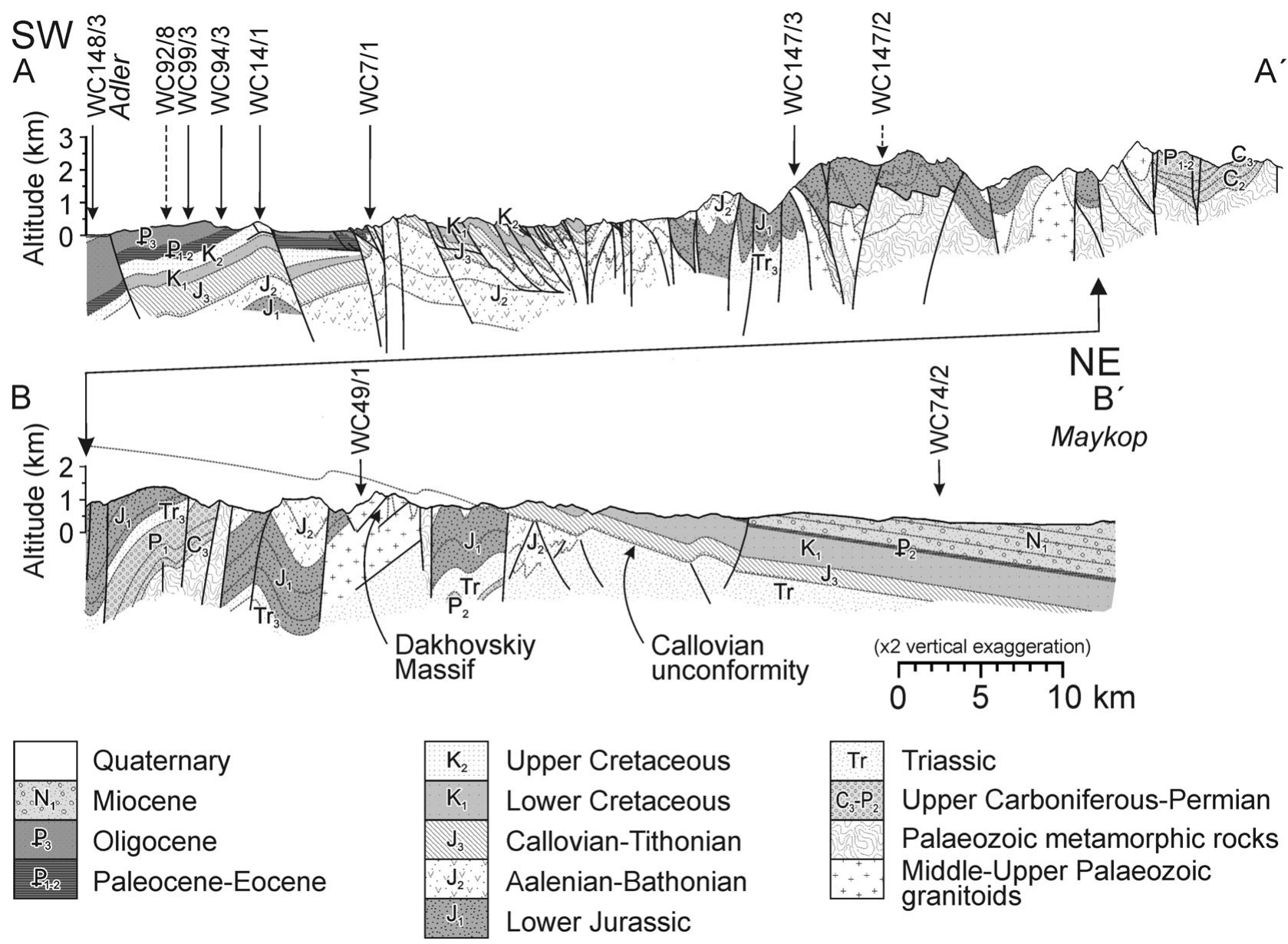

Figure 3. Cross-section through the western Greater Caucasus based on original field observations and the mapping of Melnikov, Srabony'an \& Kokarev (1994) and Lavrishchev, Prutskiy \& Semenov (2002). For location see Figure 2. For a colour version of this figure see the online Appendix at http://journals.cambridge.org/geo.

Estimates for the time of opening of the Eastern Black Sea, immediately to the south of the western Greater Caucasus, vary from the Middle Jurassic (Hossack, 2004) to the Eocene epochs (Adamia et al. 1974; Kazmin, Schreider \& Bulychev, 2000; Y1lmaz et al. 2000). A commonly attributed Paleocene to Early Eocene age (Robinson et al. 1996; Spadini, Robinson \& Cloetingh, 1996; Mikhailov et al. 1999) could make this coeval with the final closure of northern Neotethys to the south.

Age estimates for the initial uplift of the Greater Caucasus vary widely (Vincent et al. 2007). A Late Eocene-Oligocene age is the earliest generally cited (e.g. Khain \& Milanovsky, 1963; Muratov, Arkhipov \& Uspenskaya, 1984; Robinson et al. 1996; Lozar \& Polino, 1997; Nikishin et al. 2001; Saintot \& Angelier, 2002; Saintot et al. 2006a). Building on some of this earlier work, Vincent et al. (2007) used sedimentological and provenance data to demonstrate that initial compression and uplift of the western Greater Caucasus occurred around the Eocene-Oligocene boundary and speculated that this resulted from the initial collision of Arabia with Eurasia (cf. Okay, Zattin \& Cavazza, 2010).

Transpression caused the inversion of the Greater Caucasus and Adjara-Trialet basins and the formation of successor basins along the margins of the Greater Caucasus range (the Indolo-Kuban and Terek-Caspian troughs to the north and Rioni, Kartli and Kura basins to the south; Fig. 2). The amount and style of deformation across the western Greater Caucasus are disputed, with both thick- and thin-skinned tectonic models having been applied (see Saintot et al. 2006a). Southvergent thin-skinned deformation is apparent along the southern flank of the range. However, steeply dipping, elongate sinuous fault traces within the core and internal parts of the southern western Greater Caucasus (Somin, 2000; this study) suggest that thick-skinned, possibly strike-slip-influenced, deformation dominates (Figs 2,3). This is likely to be due to the influence of earlier inherited structures as well as the oblique nature of convergence. The range is highly asymmetric with its northern flank having undergone only limited amounts of fault-related deformation (Figs 2, 3).

Pulses of foreland basin subsidence, synsedimentary deformation, unconformity development and coarse-clastic progradation have been used as evidence for specific punctuated compressional events during the Mio-Pliocene evolution of the western Greater Caucasus (Nikishin et al. 1998a; Mikhailov et al. 1999; Saintot et al. 2006a). Special emphasis is placed by many studies, for instance, on a phase 
of deformation and surface uplift in late Sarmatian (Tortonian) time (e.g. Khain \& Milanovsky, 1963; Kamladze \& Kachkachshvili, 1976; Maslyaev, 1990; Zonenshain, Kuzmin \& Natapov, 1990; Milanovsky, 1991; Mikhailov et al. 1999; Saintot \& Angelier, 2002 and references therein; Meulenkamp \& Sissingh, 2003; Nikishin et al. 2003; Saintot et al. 2006a). However, it is just as likely that these events reflect switches in the locus of thrust activity within the evolving orogenic wedge (Naylor \& Sinclair, 2007), the interplay of high frequency eustatic fluctuations (Deramond et al. 1993) or the crossing of geomorphic thresholds (Hovius et al. 2001) as they do temporal variations in shortening rate.

Philip et al. (1989) erroneously proposed that the surface uplift of the range was not initiated until the Pliocene epoch. Both Meulenkamp \& Sissingh (2003) and Král \& Gurbanov (1996) also suggested that a marked increase in surface uplift and erosion occurred during this time.

Deep compressional earthquakes indicate that the Transcaucasus and South Caspian Basin are currently being subducted northward under the eastern Greater Caucasus and Apsheron Sill (Fig. 1; Jackson, 1992; Jackson et al. 2002). In contrast, there is a lack of significant seismicity across much of the western Greater Caucasus (Fig. 1). Present-day convergence rates as measured by GPS network studies also decrease from east to west, from $\sim 14 \mathrm{~mm} \mathrm{a}^{-1}$ at the eastern tip of eastern Greater Caucasus to $\sim 3 \mathrm{~mm} \mathrm{a}^{-1}$ between 40 and $44^{\circ} \mathrm{E}$ and $\sim 1 \mathrm{~mm} \mathrm{a}^{-1}$ between 36 and $40^{\circ} \mathrm{E}$ in the western Greater Caucasus (Fig. 1; Reilinger et al. 2006). This led Reilinger et al. (2006) to define a strike-slip boundary to the east of the Dziruli Massif between active shortening and rotations within the eastern Greater Caucasus and Transcaucasus and stable Eurasia to the north and west, with the study area forming part of this latter region (Fig. 4).

\section{Previous work}

Fission track (FT) analysis is the principal technique for reconstructing exhumation histories. The only major published study on the exhumation history of the Caucasus using the FT method was carried out by Král \& Gurbanov (1996). Their data would appear to show a spatial trend in cooling ages (Fig. 2). To the east of Mt Elbrus most apatite fission track (AFT) ages cluster between 7 and $4 \mathrm{Ma}$. Westward from Mt Elbrus, their AFT ages progressively increase, possibly suggesting a decrease in exhumation in this direction. However, these data were produced prior to fundamental advances in FT methodology and used the population method that is based on absolute calibration. The results may therefore be unreliable, are not directly comparable with this study, and are difficult to interpret as they contain no track length data to constrain cooling histories. Avdeev \& Niemi (2008) reported the initial findings of a more recent AFT study with cooling ages of $22 \mathrm{Ma}$ and $c .5 \mathrm{Ma}$ cited for granitic samples

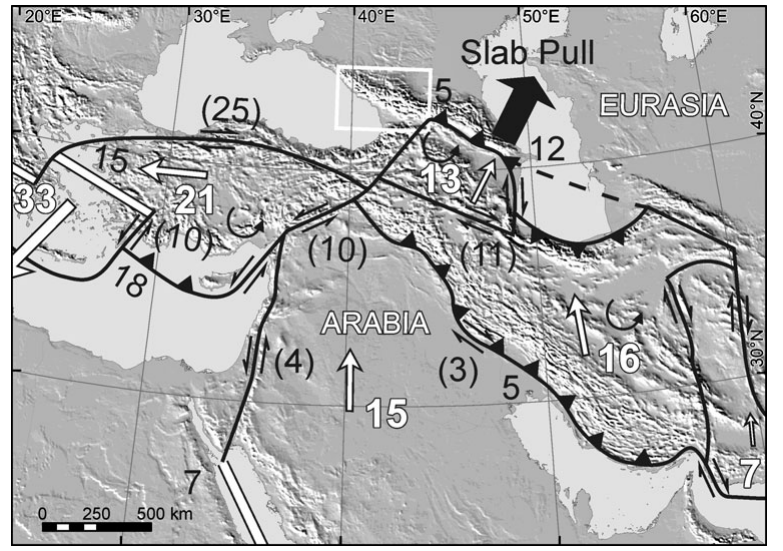

Figure 4. Schematic map of plate interactions in the ArabiaEurasia collision zone. From Reilinger et al. (2006). Heavy white lines are extensional plate boundaries, plain lines are strike-slip boundaries and lines with triangular tick marks are compressional (thrust) boundaries. Dark numbers are GPSderived slip rates $\left(\mathrm{mm} \mathrm{a}^{-1}\right)$ on block bounding faults (those in parentheses are strike-slip). White arrows and figures are GPSderived plate velocities $\left(\mathrm{mm} \mathrm{a}^{-1}\right)$ relative to Eurasia. Curved arrows show the sense of block rotations relative to Eurasia. Note that the study area (outlined in white) is considered to form part of stable Eurasia at the present day.

collected from the Mt Elbrus region (Fig. 2). Thermal modelling of the former sample yielded slow cooling rates of $\sim 3{ }^{\circ} \mathrm{C} \mathrm{Ma}^{-1}$ between $30 \mathrm{Ma}$ and $5 \mathrm{Ma}$, and higher rates of $\sim 11^{\circ} \mathrm{C} \mathrm{Ma}^{-1}$ from then on. The latter sample is reported to yield an average cooling rate of $\sim 20{ }^{\circ} \mathrm{C} \mathrm{Ma}^{-1}$.

Hess et al. (1993) and Gazis et al. (1995) studied the cooling history of the small Eldzhurtinskiy granite, to the east of Elbrus (Fig. 2), primarily using ${ }^{40} \mathrm{Ar}-{ }^{39} \mathrm{Ar}$ biotite cooling ages from borehole samples. They derived very high, but markedly different, Early Pleistocene isotherm migration rates of $4 \mathrm{~mm} \mathrm{a}^{-1}$ and $13 \mathrm{~mm} \mathrm{a}^{-1}$, respectively. The discrepancy between these studies is poorly understood, but may be because of different sampling strategies and the variable presence of excess Ar (Grün et al. 1999). Grün et al. (1999) used electron spin resonance (ESR) measurements of quartz in the same region to derive ridge isotherm migration rates of $2.5 \mathrm{~mm} \mathrm{a}^{-1}$ for the last tens of thousands of years. It is not possible to convert the isotherm migration rates in these studies accurately to exhumation rates, however, because the very young emplacement age of the Eldzhurtinskiy granite (c. 2 Ma: Grün et al. 1999) and the high cooling rates will have caused advection and the perturbation of the thermal structure of the upper crust.

Although distinct from exhumation, a number of studies have derived uplift rates for the western Greater Caucasus. Nesmeyanov (1995) documented the height of marine terraces along the Russian Black Sea coast and calculated a series of (progressively increasing) uplift rates through the mid-Pleistocene and Holocene. These rates are based on poorly constrained terrace ages. For instance, those for upper Chaudian terraces 
Table 1. Thermochronometric samples analysed in this study

\begin{tabular}{|c|c|c|c|c|c|c|c|}
\hline Sample & GPS position & Region $^{1}$ & $\begin{array}{l}\text { Location/section } \\
\quad \text { (see Fig. 2) }\end{array}$ & Lithology & $\begin{array}{l}\text { Bedrock sample } \\
\text { age (sediment } \\
\text { sample age })^{2}\end{array}$ & $\mathrm{Ma}^{3}$ & Analysis \\
\hline WG21/1 & $42^{\circ} 55.89^{\prime} \mathrm{N}, 42^{\circ} 07.20^{\prime} \mathrm{E}$ & SWGC & Inguri River & River sand & & & Cosmogenic \\
\hline WG27/5 & $42^{\circ} 39.76^{\prime} \mathrm{N}, 42^{\circ} 08.00^{\prime} \mathrm{E}$ & SWGC & Chanis River & Sandstone & (Maykopian) & $21 \pm 3$ & AFT \\
\hline WG28c/1 & $42^{\circ} 39.91^{\prime} \mathrm{N}, 42^{\circ} 08.09^{\prime} \mathrm{E}$ & SWGC & Chanis River & Sandstone & (Maykopian) & $24 \pm 1.5$ & AFT \\
\hline WG28c/5 & $42^{\circ} 39.91^{\prime} \mathrm{N}, 42^{\circ} 08.09^{\prime} \mathrm{E}$ & SWGC & Chanis River & Sandstone & (Maykopian) & $24 \pm 1.5$ & $(\mathrm{U}-\mathrm{Th}) / \mathrm{He}$ \\
\hline WG66c/2 & $42^{\circ} 37.69^{\prime} \mathrm{N}, 42^{\circ} 43.70^{\prime} \mathrm{E}$ & SWGC & Tskhenis River & Sandstone & (Chokrakian) & $15 \pm 1$ & AFT, (U-Th)/He \\
\hline WG67/8 & $42^{\circ} 35.79^{\prime} \mathrm{N}, 42^{\circ} 42.46^{\prime} \mathrm{E}$ & SWGC & Tskhenis River & Sandstone & (Maykopian) & $20 \pm 3$ & AFT, (U-Th)/He \\
\hline WG78b/1 & $42^{\circ} 05.57^{\prime} \mathrm{N}, 43^{\circ} 25.33^{\prime} \mathrm{E}$ & DM (495) & & Granitoid & Middle Jurassic & & $\mathrm{AFT}, \mathrm{ZFT}$ \\
\hline WG78c/1 & $42^{\circ} 04.20^{\prime} \mathrm{N}, 43^{\circ} 28.80^{\prime} \mathrm{E}$ & DM (846) & & Acidic gneiss & Late Palaeozoic & & AFT \\
\hline WG78e/1 & $42^{\circ} 03.00^{\prime} \mathrm{N}, 43^{\circ} 29.19^{\prime} \mathrm{E}$ & DM (1146) & & Gneiss & Late Palaeozoic & & AFT \\
\hline WG137/1 & $42^{\circ} 50.04^{\prime} \mathrm{N}, 42^{\circ} 48.99^{\prime} \mathrm{E}$ & SWGC & Tskhenis River & Psammite & $\begin{array}{l}\text { Late Palaeozoic- } \\
\text { Early Mesozoic }\end{array}$ & & AFT, ZFT \\
\hline WG141/3 & $42^{\circ} 34.86^{\prime} \mathrm{N}, 42^{\circ} 57.94^{\prime} \mathrm{E}$ & SWGC & Tskhenis River & Sandstone & (Middle Sarmatian) & $10.5 \pm 0.5$ & AFT \\
\hline WG147/2 & $42^{\circ} 39.57^{\prime} \mathrm{N}, 42^{\circ} 07.61^{\prime} \mathrm{E}$ & SWGC & Chanis River & Sandstone & (Maykopian) & $18 \pm 5$ & AFT \\
\hline WG150/1 & $\sim 43^{\circ} 26.1^{\prime} \mathrm{N}, 42^{\circ} 02.2^{\prime} \mathrm{E}$ & CWGC & & Granitoid & Palaeozoic & & AFT \\
\hline WG151/1 & $\sim 43^{\circ} 26.1^{\prime} \mathrm{N}, 42^{\circ} 02.2^{\prime} \mathrm{E}$ & CWGC & & Granitoid & Palaeozoic & & AFT, ZFT \\
\hline WG153/1 & $\sim 43^{\circ} 25.1^{\prime} \mathrm{N}, 42^{\circ} 13.0^{\prime} \mathrm{E}$ & CWGC & & Granitoid & Palaeozoic & & ZFT \\
\hline WC7/1 & $43^{\circ} 35.63^{\prime} \mathrm{N}, 40^{\circ} 00.88^{\prime} \mathrm{E}$ & SWGC & Mzimta River & Sandstone & (Maykopian) & $33 \pm 0.6$ & AFT \\
\hline WC14/1 & $43^{\circ} 31.442^{\prime} \mathrm{N}, 40^{\circ} 00.077^{\prime} \mathrm{E}$ & SWGC & Mzimta River & Sandstone & Cenomanian & & AFT \\
\hline WC39/2 & $43^{\circ} 52.28^{\prime} \mathrm{N} 39^{\circ} 23.81^{\prime} \mathrm{E}$ & SWGC & & Sandstone & Middle-Late Aptian & & AFT \\
\hline WC49/1 & $44^{\circ} 09.80^{\prime} \mathrm{N}, 40^{\circ} 08.49^{\prime} \mathrm{E}$ & CWGC & Dakhovskiy Massif & Granitoid & Late Palaeozoic & & AFT, ZFT \\
\hline $\mathrm{WC} 74 / 2$ & $44^{\circ} 28.9346^{\prime} \mathrm{N} 40^{\circ} 11.53^{\prime} \mathrm{E}$ & NWGC & Belaya River & Sandstone & (Late Karaganian) & $13.3 \pm 0.4$ & AFT \\
\hline $\mathrm{WC} 79 / 2$ & $44^{\circ} 29.41^{\prime} \mathrm{N} 39^{\circ} 43.89^{\prime} \mathrm{E}$ & NWGC & Belaya River & Sandstone & (Late Sarmatian) & $8.8 \pm 1.2$ & AFT \\
\hline WC84/1 & $44^{\circ} 19.88^{\prime} \mathrm{N}, 39^{\circ} 48.39^{\prime} \mathrm{E}$ & NWGC & Pshekha River & Schist & (Maykopian) & $27 \pm 3$ & AFT \\
\hline WC $92 / 8$ & $43^{\circ} 35.94^{\prime} \mathrm{N} 39^{\circ} 45.28^{\prime} \mathrm{E}$ & SWGC & Sochi & Sandstone & (Maykopian) & $27 \pm 2.5$ & AFT \\
\hline WC $94 / 3$ & $43^{\circ} 30.40^{\prime} \mathrm{N} 40^{\circ} 01.55^{\prime} \mathrm{E}$ & SWGC & Mzimta River & Sandstone & (Maykopian) & $33 \pm 0.6$ & AFT \\
\hline WC99/3 & $43^{\circ} 28.52^{\prime} \mathrm{N} 40^{\circ} 01.88^{\prime} \mathrm{E}$ & SWGC & Mzimta River & Sandstone & (Maykopian) & $31 \pm 0.5$ & AFT \\
\hline WC120/1 & $43^{\circ} 58.393^{\prime} \mathrm{N} 40^{\circ} 57.718^{\prime} \mathrm{E}$ & NWGC & Mala Laba River & Sandstone & Early Jurassic & & AFT \\
\hline WC123/1 & $44^{\circ} 18.736^{\prime} \mathrm{N} 40^{\circ} 56.287^{\prime} \mathrm{E}$ & NWGC & Mala Laba River & Sandstone & (Maykopian) & $24 \pm 2$ & AFT \\
\hline WC128/1 & $44^{\circ} 31.414^{\prime} \mathrm{N} 39^{\circ} 43.639^{\prime} \mathrm{E}$ & NWGC & Psheka River & Sandstone & (Meotian) & $6.7 \pm 0.8$ & AFT \\
\hline WC133/2 & $45^{\circ} 05.198^{\prime} \mathrm{N} 37^{\circ} 26.528^{\prime} \mathrm{E}$ & WGC & & $\begin{array}{l}\text { Sandstone } \\
\text { clast }\end{array}$ & (Pontian) & $5.3 \pm 0.5$ & AFT \\
\hline WC147/2 & $43^{\circ} 42.234^{\prime} \mathrm{N} 40^{\circ} 16.236^{\prime} \mathrm{E}$ & $\begin{array}{l}\text { CWGC } \\
\text { source }\end{array}$ & $\begin{array}{l}\text { Laura River } \\
\text { (Mzimta tributary) }\end{array}$ & Gneiss & Late Palaeozoic & & AFT \\
\hline WC147/3 & $43^{\circ} 42.234^{\prime} \mathrm{N} 40^{\circ} 16.236^{\prime} \mathrm{E}$ & $\begin{array}{l}\text { CWGC } \\
\text { source }\end{array}$ & $\begin{array}{l}\text { Laura River } \\
\text { (Mzimta tributary) }\end{array}$ & Granite & Late Palaeozoic & & AFT \\
\hline WC148/3 & $43^{\circ} 24.689^{\prime} \mathrm{N} 39^{\circ} 59.225^{\prime} \mathrm{E}$ & SWGC & Mzimta River & Granite & (Pontian) & $5.3 \pm 0.5$ & AFT \\
\hline WC149/3 & $43^{\circ} 31.124^{\prime} \mathrm{N} 39^{\circ} 51.061^{\prime} \mathrm{E}$ & SWGC & Sochi & Sandstone & (Maykopian) & $20 \pm 3.5$ & AFT \\
\hline
\end{tabular}

${ }^{1}$ CWGC - central western Greater Caucasus; NWGC - northern western Greater Caucasus; SWGC - southern western Greater Caucasus; DM - Dziruli Massif (sample height; metres).

${ }^{2}$ As defined in the text (Section 4); sediment sample ages employ the Paratethyan stratigraphic scheme (see Jones \& Simmons, 1997).

${ }^{3}$ Depositional ages are estimated by applying the absolute age data of Gradstein, Ogg \& Smith (2004) to the Paratethyan correlation schemes of Jones \& Simmons (1997), Vasiliev et al. (2005) and Popov et al. (2006).

documented at $110-140 \mathrm{~m}$ asl between Tuapse and Sochi vary from about $400 \mathrm{ka}$ (Nesmeyanov, 1995) to about $600 \mathrm{ka}$ (Matoshko, Gozhik \& Semenenko, 2009). This would imply rock uplift rates of $\sim 0.2$ $0.3 \mathrm{~mm} \mathrm{a}^{-1}$. As a comparison, upper Sarmatian marine sediments to the north of the Dziruli Massif at $2050 \mathrm{~m}$ (Kandelaki \& Kakhadze, 1956) provide minimum rock uplift rates of $\sim 0.25 \mathrm{~mm} \mathrm{a}^{-1}$ over the last c. 9 Ma.

Estimates for the rate of Quaternary surface uplift in the core of the western Greater Caucasus vary from $1.4 \mathrm{~mm} \mathrm{a}^{-1}$ (Mikhailov, Smolyaninova \& Sebrier, 2002) to $12 \mathrm{~mm} \mathrm{a}^{-1}$ (Philip et al. 1989). Values of total uplift of the same include $\sim 1-2 \mathrm{~km}$ (Milanovsky, 2008) and $\sim 4 \mathrm{~km}$ (Artemjev, 1980; Belousov \& Enman, 1999). These estimates are derived from a variety of geomorphological and geophysical techniques, the reliability of which is difficult to assess. Present-day (GPS-derived) surface uplift rates for the Eldzhurtinskiy granite are $6-8 \mathrm{~mm} \mathrm{a}^{-1}$ (Grün et al. 1999).

\section{Thermochronometric methodologies}

Thirty-nine new thermochronometric analyses are presented in this study. These comprise 30 apatite fission track analyses, 5 zircon fission track (ZFT) analyses, 3 apatite $(\mathrm{U}-\mathrm{Th}) / \mathrm{He}$ radiometric age dates and a single detrital ${ }^{10} \mathrm{Be}$ cosmogenic nuclide concentration determination (Table 1).

The FT and apatite (U-Th)/He analyses were carried out by the London Thermochronometry Group at University and Birkbeck College, University of London, UK, using the approaches outlined by Gallagher, Brown \& Johnson (1998) and Donelick, O'Sullivan \& Ketcham (2005). Samples for FT analysis were mounted, polished, etched and then packed with muscovite external detectors and Corning glass dosimeters and irradiated in the well-thermalized $(\mathrm{Cd}$ ratio for $\mathrm{Au}>100$ ) Hifar Reactor at Lucas Heights in Australia. Fission-track densities were measured using an optical microscope at $1250 \times$ magnification with an oil objective. Ages $( \pm 1 \sigma)$ were calibrated 
Table 2. Apatite and zircon fission track results

\begin{tabular}{|c|c|c|c|c|c|c|c|c|c|c|c|c|c|c|c|c|}
\hline \multirow[b]{3}{*}{ Sample no. } & \multirow[b]{3}{*}{ Analysis } & \multirow{3}{*}{$\begin{array}{l}\text { No. } \\
\text { grains }\end{array}$} & \multicolumn{6}{|c|}{ Track densities $\left(\times 10^{6} \operatorname{tr} \mathrm{cm}^{-2}\right)$} & & & \multirow{3}{*}{$\begin{array}{l}\text { Central age } \\
(\mathrm{Ma} \pm 1 \sigma)\end{array}$} & \multirow{3}{*}{$\begin{array}{c}\text { Old comp } \\
(\mathrm{Ma} \pm 1 \sigma)\end{array}$} & \multirow{3}{*}{$\begin{array}{l}\text { Young comp } \\
(\mathrm{Ma} \pm 1 \sigma)\end{array}$} & \multirow{3}{*}{$\begin{array}{l}\text { Mean track } \\
\text { length }(\mu \mathrm{m})\end{array}$} & \multirow{3}{*}{$\begin{array}{l}\text { S.D. } \\
(\mu \mathrm{m})\end{array}$} & \multirow{3}{*}{$\begin{array}{l}\text { No. } \\
\text { tracks }\end{array}$} \\
\hline & & & \multicolumn{2}{|c|}{ Dosimeter } & \multicolumn{2}{|c|}{ Spontaneous } & \multicolumn{2}{|c|}{ Induced } & \multicolumn{2}{|c|}{ Age dispersion } & & & & & & \\
\hline & & & $\rho_{\mathrm{d}}$ & $\mathrm{N}_{\mathrm{d}}$ & $\rho_{\mathrm{s}}$ & $\mathrm{N}_{\mathrm{s}}$ & $\rho_{\mathrm{i}}$ & $\mathrm{N}_{\mathrm{i}}$ & $\mathrm{P}_{\mathrm{x}^{2}}$ & $\mathrm{RE} \%$ & & & & & & \\
\hline WG27/5 & AFT & 31 & 1.117 & 3095 & 0.450 & 437 & 1.471 & 1427 & 0 & 69.6 & $57.4 \pm 8.4$ & $157 \pm 16$ & $31 \pm 3$ & $13.24 \pm 0.46$ & 2.27 & 24 \\
\hline WG $28 \mathrm{c} / 1$ & AFT & 25 & 1.123 & 6228 & 0.502 & 484 & 0.775 & 748 & $<1$ & 52 & $110.0 \pm 13.9$ & $152 \pm 12$ & $34 \pm 6$ & $14.08 \pm 0.29$ & 1.37 & 22 \\
\hline WG66c/2 & AFT & 34 & 1.264 & 7010 & 0.066 & 719 & 0.938 & 1028 & 0 & 42.13 & $168.9 \pm 15.9$ & $192 \pm 12$ & $55 \pm 11$ & $12.96 \pm 0.25$ & 1.15 & 21 \\
\hline WG67/8 & AFT & 37 & 1.123 & 6228 & 0.494 & 561 & 0.966 & 1098 & $<1$ & 41 & $101.0 \pm 9.2$ & $125 \pm 9$ & $41 \pm 5$ & $13.37 \pm 0.35$ & 1.72 & 24 \\
\hline WG78b/1 & AFT & 21 & 1.123 & 6228 & 0.571 & 626 & 0.931 & 1021 & 62.0 & 1 & $115.3 \pm 6.1$ & & & $12.14 \pm 0.23$ & 2.05 & 83 \\
\hline WG78b/1 & ZFT & 18 & 0.346 & 2438 & 11.780 & 3820 & 1.539 & 499 & 60.0 & 4 & $166.1 \pm 8.8$ & & & No data & & \\
\hline WG78c/1 & AFT & 17 & 1.123 & 6228 & 2.130 & 871 & 2.514 & 1028 & 1.0 & 16 & $159.7 \pm 10.4$ & & & $11.62 \pm 0.19$ & 1.91 & 102 \\
\hline WG78e/1 & AFT & 21 & 1.123 & 6228 & 0.606 & 481 & 0.662 & 526 & 89.0 & 0 & $171.2 \pm 11.0$ & & & $13.66 \pm 0.14$ & 1.44 & 110 \\
\hline WG137/1 & AFT & 11 & 1.123 & 6228 & 0.034 & 15 & 2.625 & 1157 & 70.0 & 1 & $2.5 \pm 0.6$ & & & No data & & \\
\hline WG137/1 & ZFT & 20 & 3.240 & 2245 & 22.06 & 6328 & 3.210 & 921 & 7 & 9.1 & $139.6 \pm 6.5$ & & & No data & & \\
\hline WG141/3 & AFT & 33 & 1.123 & 6228 & 0.608 & 468 & 0.879 & 673 & $<1$ & 33 & $141.1 \pm 12.8$ & $158 \pm 11$ & $59 \pm 9$ & $12.30 \pm 0.41$ & 1.93 & 22 \\
\hline WG147/2 & AFT & 27 & 1.264 & 7010 & 0.554 & 421 & 1.390 & 1056 & 0 & 42.1 & $86.1 \pm 9.2$ & $126 \pm 11$ & $52 \pm 5$ & $12.70 \pm 0.39$ & 1.75 & 20 \\
\hline WG150/1 & AFT & 20 & 1.264 & 7010 & 0.987 & 1301 & 6.045 & 7968 & 0 & 24.2 & $34.3 \pm 2.2$ & & & $12.73 \pm 0.17$ & 1.67 & 100 \\
\hline WG151/1 & AFT & 20 & 1.264 & 7010 & 0.646 & 666 & 4.957 & 5112 & 0 & 24.4 & $27.9 \pm 2.0$ & & & No data & & \\
\hline WG151/1 & ZFT & 4 & 3.240 & 2245 & 15.04 & 1084 & 1.124 & 81 & 88 & 0 & $269.6 \pm 31.6$ & & & No data & & \\
\hline WG153/1 & ZFT & 12 & 3.240 & 2245 & 15.27 & 2243 & 1.382 & 203 & 36 & 8.7 & $223.2 \pm 18.0$ & & & No data & & \\
\hline WC7/1 & AFT & 8 & 1.388 & 5772 & 0.391 & 77 & 0.915 & 230 & 29.7 & 8.1 & $78.5 \pm 10.7$ & & & Too few & & \\
\hline WC14/1 & AFT & 23 & 1.388 & 5772 & 0.249 & 370 & 0.582 & 939 & 3.4 & 21.9 & $91.9 \pm 7.3$ & & & $14.36 \pm 0.21$ & 1.49 & 50 \\
\hline WC39/2 & AFT & 32 & 1.388 & 5772 & 1.076 & 789 & 2.111 & 1585 & 0.0 & 27.1 & $117.1 \pm 8.0$ & & & $12.39 \pm 0.35$ & 1.63 & 22 \\
\hline WC49/1 & AFT & 20 & 1.012 & 2762 & 3.868 & 1855 & 5.155 & 2472 & 7.6 & 9.4 & $126.5 \pm 5.3$ & & & $11.36 \pm 0.20$ & 2.00 & 100 \\
\hline WC49/1 & ZFT & 8 & 0.408 & 2921 & 22.88 & 2260 & 2.428 & 212 & 2 & 21.3 & $271.5 \pm 28.8$ & & & No data & & \\
\hline $\mathrm{WC} 74 / 2$ & AFT & 12 & 1.388 & 5772 & 1.763 & 328 & 2.130 & 390 & 13.6 & 16.8 & $193.0 \pm 18.4$ & & & No data & & \\
\hline WC79/2 & AFT & 20 & 1.388 & 5772 & 3.492 & 1575 & 5.781 & 2671 & 0.0 & 35.8 & $138.4 \pm 12.4$ & & & $12.57 \pm 0.20$ & 1.73 & 74 \\
\hline WC $84 / 1$ & AFT & 20 & 1.024 & 2762 & 0.846 & 848 & 2.533 & 2538 & 1.2 & 15.9 & $57.3 \pm 3.3$ & & & $12.93 \pm 0.20$ & 1.97 & 101 \\
\hline WC92/8 & AFT & 11 & 1.388 & 5772 & 1.355 & 225 & 2.407 & 482 & 0.5 & 34.0 & $112.8 \pm 16.1$ & & & $12.79 \pm 0.51$ & 1.62 & 10 \\
\hline WC94/3 & AFT & 23 & 1.388 & 5772 & 0.569 & 280 & 1.211 & 574 & 0.0 & 42.3 & $115.3 \pm 14.0$ & & & None & & \\
\hline WC99/3 & AFT & 31 & 1.388 & 5772 & 0.661 & 530 & 1.143 & 958 & 43.6 & 12.4 & $124.2 \pm 8.0$ & & & $13.18 \pm 0.28$ & 1.29 & 20 \\
\hline $\mathrm{WC} 120 / 1$ & AFT & 24 & 1.388 & 5772 & 0.479 & 492 & 1.057 & 1217 & 0.0 & 39.9 & $117.7 \pm 12.1$ & & & $13.43 \pm 0.47$ & 1.71 & 13 \\
\hline WC123/1 & AFT & 11 & 1.388 & 5772 & 1.769 & 426 & 2.272 & 569 & 42.5 & 4.3 & $175.7 \pm 12.1$ & & & $13.75 \pm 0.43$ & 1.54 & 13 \\
\hline WC128/1 & AFT & 20 & 1.388 & 5772 & 3.322 & 2057 & 5.319 & 3291 & 0.0 & 36.6 & $139.0 \pm 12.7$ & & & $13.12 \pm 0.16$ & 1.57 & 100 \\
\hline $\mathrm{WC} 133 / 2$ & AFT & 9 & 1.388 & 5772 & 3.413 & 302 & 2.685 & 253 & 0.1 & 34.9 & $264.2 \pm 40.0$ & & & Too few & & \\
\hline $\mathrm{WC} 147 / 2$ & AFT & 20 & 1.388 & 5772 & 0.480 & 240 & 2.687 & 1335 & 0.2 & 31.4 & $43.3 \pm 4.4$ & & & $13.33 \pm 0.37$ & 2.36 & 40 \\
\hline $\mathrm{WC} 147 / 3$ & AFT & 21 & 1.388 & 5772 & 0.872 & 470 & 7.050 & 4043 & 0.0 & 26.4 & $28.0 \pm 2.2$ & & & $14.14 \pm 0.21$ & 2.05 & 100 \\
\hline WC148/3 & AFT & 22 & 1.388 & 5772 & 0.075 & 59 & 1.147 & 940 & 45.1 & 4.8 & $14.7 \pm 2.0$ & & & None & & \\
\hline WC149/3 & AFT & 16 & 1.388 & 5772 & 0.905 & 291 & 1.640 & 537 & 1.7 & 29.6 & $110.2 \pm 12.8$ & & & $12.99 \pm 0.38$ & 1.78 & 21 \\
\hline
\end{tabular}

Analyses by external detector method using 0.5 for the $4 \pi / 2 \pi$ geometry correction factor.

Ages were calculated using dosimeter glass CN-5; (apatite) $\zeta_{\mathrm{CN} 5}=338 \pm 4$; CN-2 (zircon) $\zeta_{\mathrm{CN} 2}=127 \pm 4$ calibrated by multiple analyses of IUGS apatite and zircon age standards (see Hurford, 1990). $\mathrm{P} \chi^{2}$ is probability for obtaining $\chi^{2}$ value for $\mathrm{v}$ degrees of freedom, where $\mathrm{v}=$ no. crystals -1 .

Central age is a modal age, weighted for different precisions of individual crystals (see Galbraith \& Laslett, 1993). Old and young compositional ages are determined using track length radial plot distributions (see Fig. A1 in online Appendix at http://journals.cambridge.org/geo). 
Table 3. Apatite (U-Th)/He dating results from Oligo-Miocene sediment samples, West Georgian Greater Caucasus

\begin{tabular}{|c|c|c|c|c|c|c|c|c|c|c|c|c|c|}
\hline Sample & $\begin{array}{l}4 \mathrm{He} \\
(\mathrm{ncc})\end{array}$ & $\begin{array}{l}\mathrm{HB} \\
\text { (ncc) }\end{array}$ & $\begin{array}{c}\% \mathrm{SD} \\
\text { in } \mathrm{Q} \pm\end{array}$ & $4 \mathrm{He}$ (atoms) & Absolute \pm & ${ }^{238} \mathrm{U}$ (ng) & $\pm(\%)$ & $\begin{array}{c}{ }^{232} \mathrm{Th} \\
\text { (ng) }\end{array}$ & $\pm(\%)$ & $\begin{array}{l}\text { Uncorrected } \\
\text { He age }(\mathrm{Ma})\end{array}$ & $\begin{array}{c}\mathrm{F}_{\mathrm{T}} \\
\text { corrected } \\
\text { He age }\end{array}$ & $\pm 1 \sigma$ & $\mathrm{F}_{\mathrm{T}}$ factor \\
\hline WG $28 \mathrm{c} / 5$ & 0.291 & 0.025 & 0.652 & $7.147 \mathrm{E}+09$ & $4.660 \mathrm{E}+07$ & 0.0438 & 0.024 & 0.283 & 0.118 & 20.349 & 25.43 & 0.13 & 0.80 \\
\hline WG67/8 & 0.337 & 0.023 & 0.295 & $8.436 \mathrm{E}+09$ & $2.489 \mathrm{E}+07$ & 0.0294 & 0.047 & 0.157 & 0.295 & 40.06 & 49.46 & 0.14 & 0.81 \\
\hline WG66c/2 & 0.508 & 0.022 & 0.522 & $1.306 \mathrm{E}+10$ & $6.816 \mathrm{E}+07$ & 0.0744 & 0.032 & 0.265 & 0.223 & 30.32 & 39.90 & 0.16 & 0.76 \\
\hline
\end{tabular}

$\mathrm{HB}$ - Hot blank; $\mathrm{F}_{\mathrm{T}}$ is the grain dimension correction factor to account for helium lost by ejection of alpha particles.

by the zeta method (Hurford \& Green, 1983). FT results are presented in Table 2, with AFT length data and radial plots being contained in the online Appendix (http://journals.cambridge.org/geo). The bestfit thermal models for the AFT data are presented in Figure 5 and were modelled using HeFTy (Ketcham in Ehlers et al. 2005), taking into account apatite sample composition.

Three types of FT samples are distinguished: (1) crystalline/metamorphosed basement, (2) Mesozoic sedimentary rocks that contain fission tracks annealed after deposition, and (3) Oligo-Miocene sedimentary rocks (or crystalline clasts contained therein) that have not undergone significant post-depositional burial. The former two types are referred to as bedrock samples in the discussion below and record the thermal history of the sample's locations. The latter records the more regional and complex palaeothermal history of these sediments' source areas prior to erosion and deposition. Palaeocurrent and provenance analyses indicate that these sediments were derived from the region of the present-day high Caucasus (Vincent et al. 2007). The geographic positions of all the FT samples are shown on Figure 2, along with a graphic representation of the FT cooling age of the bedrock samples and the lag time between the AFT cooling and depositional ages of the Oligo-Miocene sediment samples.

Sample cooling histories are converted to eroded crustal section $(\mathrm{km})$ by dividing temperature loss (mineral closure minus surface temperature; ${ }^{\circ} \mathrm{C}$ ) by average geothermal gradient $\left({ }^{\circ} \mathrm{C} \mathrm{km}^{-1}\right)$. Mineral closure temperatures are dependent on cooling rates, were calculated using the CLOSURE program (Brandon in Ehlers et al. 2005) and are stated in the text. Rapid exhumation causes thermal advection, increased geothermal gradients and an overestimation of lost section due to denudation (Brown \& Summerfield, 1997). Erosion rate estimates were corrected for these effects using the AGE2EDOT program (Brandon in Ehlers et al. 2005). An average surface temperature of $10^{\circ} \mathrm{C}$ is adopted.

Geothermal gradients derived from exploration wells along the margins of the western Greater Caucasus vary, depending on the age and lithology of the sedimentary succession (Sukharev, Taranukha \& Vlasov, 1964). They are generally lower on the southern side of the range (e.g. $\sim 20-30{ }^{\circ} \mathrm{C} \mathrm{km}^{-1}$ around Sochi and $\sim 30^{\circ} \mathrm{C} \mathrm{km}^{-1}$ near Poti) than on the northern side (e.g. $\sim 40-55^{\circ} \mathrm{C} \mathrm{km}^{-1}$ around Maykop and $\sim 40{ }^{\circ} \mathrm{C} \mathrm{km}^{-1}$ near Mineral'nyye Vody) (Sukharev, Taranukha \& Vlasov, 1964). A geothermal gradient of $\sim 40$ $45^{\circ} \mathrm{C} \mathrm{km}^{-1}$ was calculated from borehole data within the Eldzhurtinskiy granite, in the northern part of the crystalline core of the range (Hess et al. 1993; Gazis et al. 1995; Grün et al. 1999). An average geothermal gradient value of $40^{\circ} \mathrm{C} \mathrm{km}^{-1}$ is adopted here. This inevitably introduces uncertainty, and it results, for instance, in exhumation estimates being lower than if the global average of $30{ }^{\circ} \mathrm{C} \mathrm{km}^{-1}$ were adopted (these values are also included in parentheses). Such estimates, however, are necessary if the relative magnitude of exhumation in the region is to be illustrated.

Apatite (U-Th)/He determinations were made on a single aliquot of two to four apatite grains, typically between 100-250 $\mu \mathrm{m}$ long and $60-150 \mu \mathrm{m}$ wide. Evolved helium was spiked with ${ }^{3} \mathrm{He}$, and ${ }^{4} \mathrm{He} /{ }^{3} \mathrm{He}$ values were determined on a quadrupole mass spectrometer after quantitative $\mathrm{He}$ degassing of apatite at $\sim 1000^{\circ} \mathrm{C}$ for $30 \mathrm{~min}$ in a furnace. Grains were retrieved from the vacuum system, dissolved in $\mathrm{HNO}_{3}$, spiked with ${ }^{230} \mathrm{Th}$ and ${ }^{235} \mathrm{U}$, and analysed for $\mathrm{U}$ and Th by Inductively Coupled Plasma Mass Spectrometry. Reported He ages have been corrected for alpha ejection effects based on measured grain dimensions (Farley, Wolf \& Silver, 1996) using the procedure of Gautheron, Tassan-Got \& Farley (2006). Each age typically comprises 3-4 replicates, the mean of which is reported in Table 3. The estimated analytical uncertainty for $\mathrm{AHe}$ ages based on the Durango age standard is $7 \%(2 \sigma)$. These are the default uncertainty values used on a sample unless the standard deviation from the sample replicate ages is higher, in which case the latter is used.

Quartz for the detrital ${ }^{10} \mathrm{Be}$ cosmogenic nuclide analysis was physically and chemically isolated by the Geochemical Group of the University of Bern, Switzerland, and then spiked with a known proportion of ${ }^{9} \mathrm{Be}$ using a method simplified from von Blanckenburg, Belshaw \& O'Nions (1996). ${ }^{10} \mathrm{Be}$ concentrations were then calculated using accelerator mass spectrometry at the PSI/ETH facility in Zurich, Switzerland, to determine the ${ }^{10} \mathrm{Be} /{ }^{9} \mathrm{Be}$ value and the concentration of $\mathrm{Be}$ in the quartz in a method described by Kubik et al. (1998). Predicted cosmogenic nuclide flux was adjusted for mean elevation, latitude and topography of the catchment area of the Inguri River upstream of the river sample site (WG21/1). The erosion rate derived 

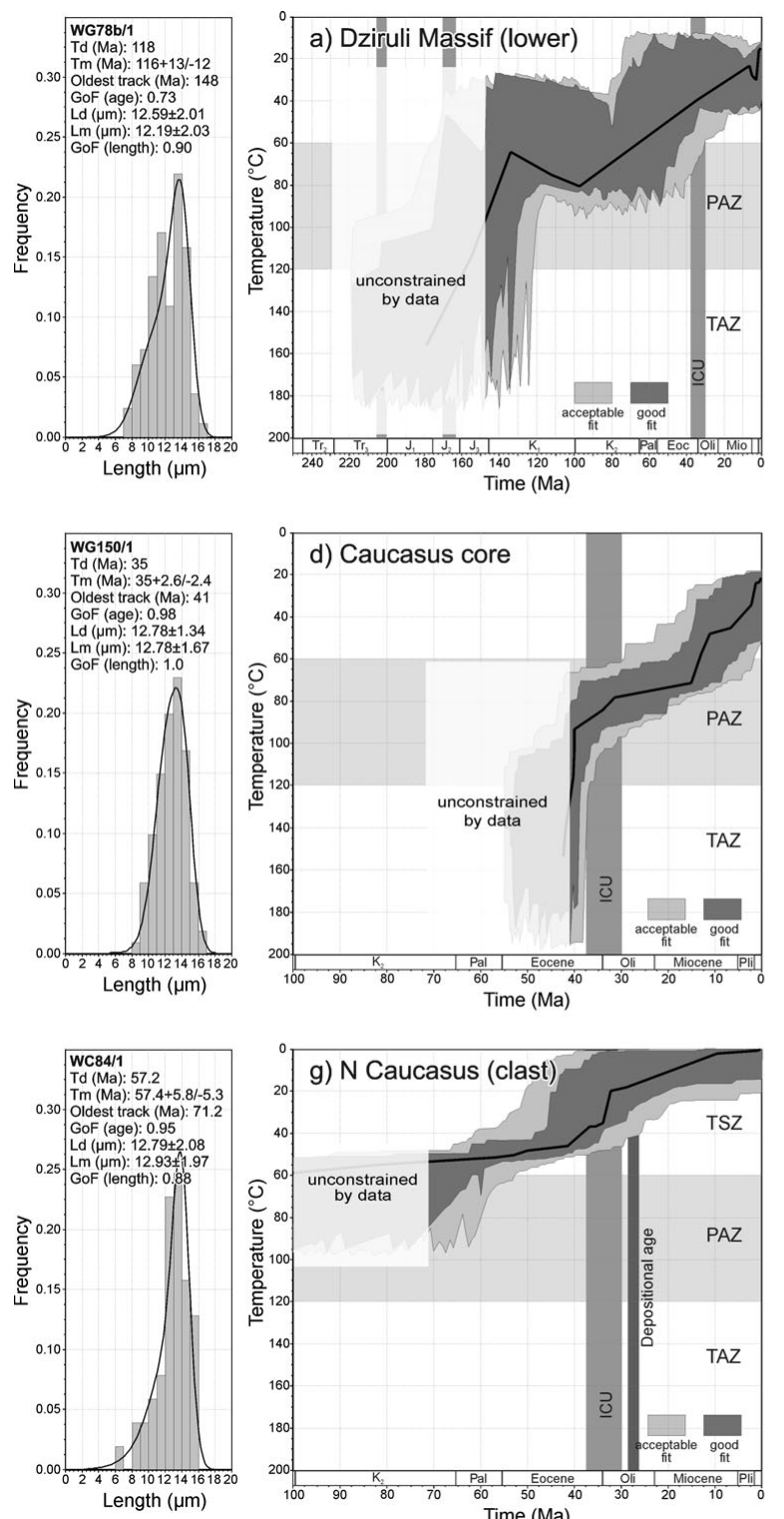

Time (Ma)
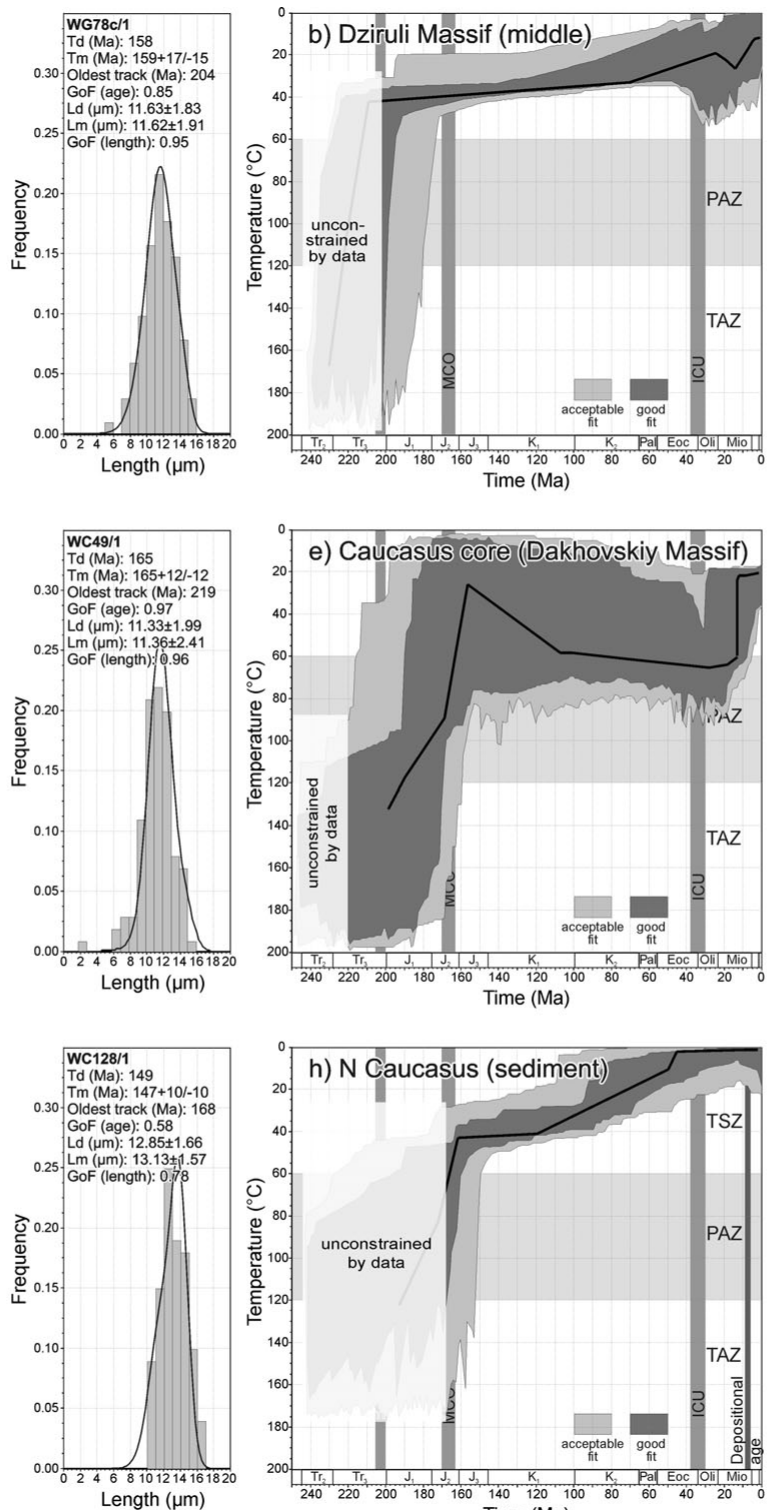
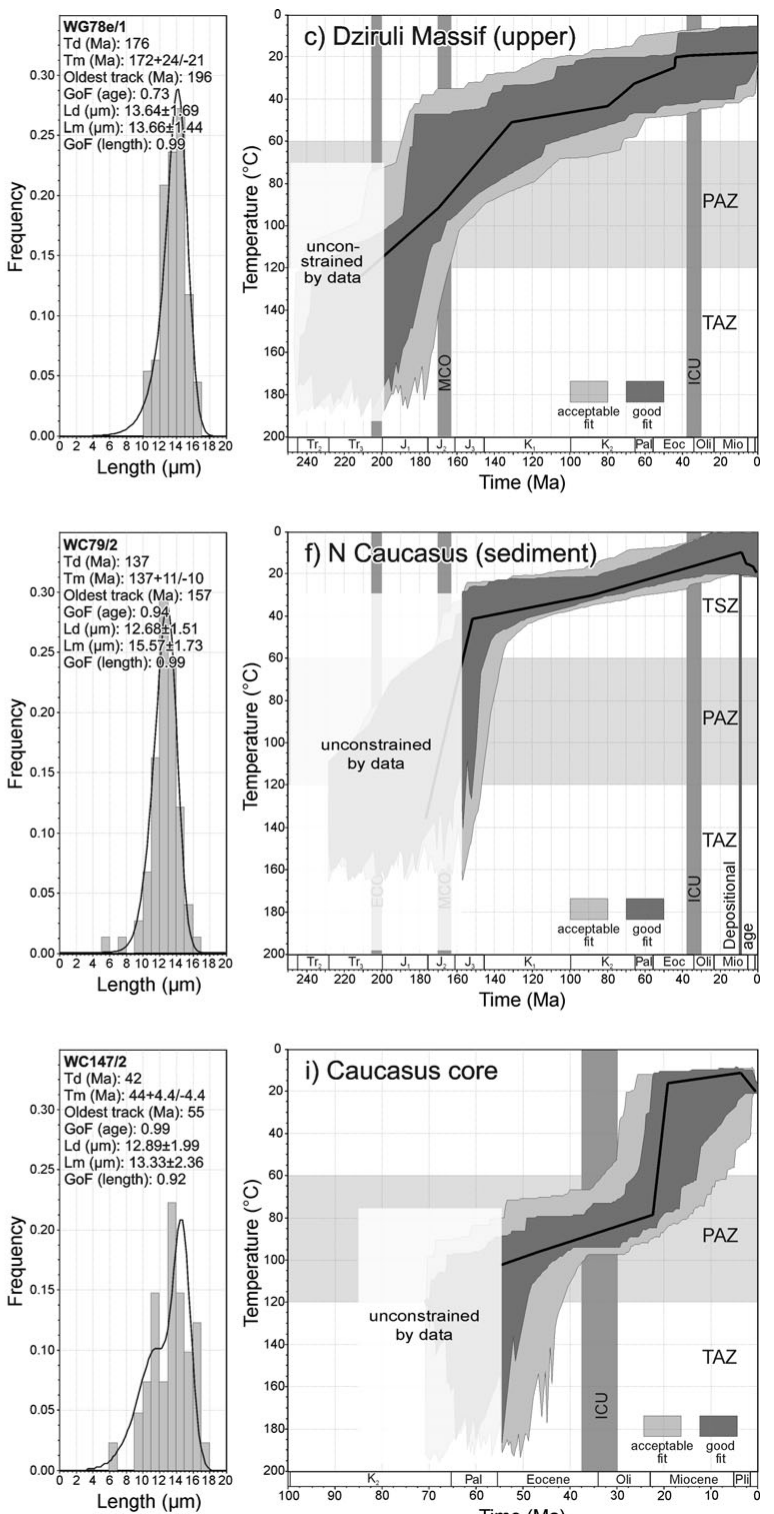

Figure 5. Best-fit thermal models for AFT samples from the Dziruli Massif and western Greater Caucasus listed in alpha-numeric order. One hundred good thermal paths were obtained for each model. The approximate intervals of the ECO (early Cimmerian orogeny), MCO (middle Cimmerian orogeny) and ICU (initial Caucasus uplift) are shown, as are the approximate temperature ranges of the apatite TAZ (total annealing zone), PAZ (partial annealing zone) and TSZ (total stability zone). The dark and light shaded areas encompass $1 \sigma$ (good) and $2 \sigma$ (acceptable) confidence limits, respectively, and the lines correspond to the most probable thermal histories. Goodness of fit (GoF) gives an indication of the fit between observed and predicted values (values close to 1 are best). The geological timescale is from Gradstein, Ogg \& Smith (2004). For a colour version of this figure see the online Appendix at http://journals.cambridge.org/geo. 
for this sample and the area it relates to are shown on Figure 2.

\section{Analytical data}

\section{5.a. Bedrock samples}

\section{5.a.1. Core of the western Greater Caucasus}

Introduction. Six crystalline basement samples were analysed from the core of the western Greater Caucasus (Table 1; Fig. 2). Three were derived from its northern margin close to Mt Elbrus (samples WG150/1, WG151/1 and WG153/1). One sample was from the northwesternmost granodioritic body exposed in the western Greater Caucasus, the Dakhovskiy Massif on the Belaya River (sample WC49/1). The remaining two samples, although collected from the headwaters of the Mzimta River, were petrologically matched with Late Palaeozoic crystalline bodies at the southern margin of the crystalline core of the range (as shown on Fig. 2; samples WC147/2 and WC147/3). AFT analysis was carried out on all but sample WG153/1, while ZFT analysis was also carried out on samples WG151/1, WG153/1 and WC49/1 (Table 1).

Results. Sample WG151/1 yields an AFT central age of $28 \pm 2 \mathrm{Ma}$ (Table 2). However, because no confined track lengths were present, it is unclear if this age records the time of rapid cooling through the partial annealing zone (PAZ) or a more protracted history. For this reason the apatite in adjacent sample WG150/1 was also analysed. This gave an age of $34 \pm 2 \mathrm{Ma}$ and a mean track length of $12.73 \pm 0.17 \mu \mathrm{m}$ based on 100 measurements (Table 2). This age, although not identical to that obtained in WG151/1, is within $2 \sigma$ error, and thus it is reasonable to assume both samples have experienced a similar thermal history. The track length distribution for sample WG150/1 is unimodal and relatively long (Fig. 5d). The lack of a tail of short tracks is consistent with a simple, fairly rapid cooling history.

The best-fit thermal model for sample WG150/1 displays a strong goodness of fit ( $\mathrm{GoF}$ ) to the analytical data (Fig. 5d). The sample displays a relatively uniform Oligocene to Present cooling path, although there may have been an increase in cooling from around $1{ }^{\circ} \mathrm{C} \mathrm{Ma}^{-1}$ to $3{ }^{\circ} \mathrm{C} \mathrm{Ma}^{-1}$ during Middle Miocene time (c. $15 \mathrm{Ma}$; Fig. $5 \mathrm{~d}$ ).

ZFT results for sample WG151/1, based on only four single grain ages, yield an imprecise cooling age of $270 \pm 32 \mathrm{Ma}$ (Table 2). A more precise ZFT age of $223 \pm 18 \mathrm{Ma}$ was obtained from sample WG153/1. When paired with the AFT cooling data, these ages record the relative thermal stability of the crystalline core of the western Greater Caucasus during Mesozoic and early Cenozoic time. Cooling from $\sim 200^{\circ} \mathrm{C}$ during Middle Permian-Middle Triassic time to $\leq 100^{\circ} \mathrm{C}$ by the end of Eocene-middle Oligocene time is equivalent to an average cooling rate of $\sim 0.5^{\circ} \mathrm{C} \mathrm{Ma}^{-1}$. These results also limit the amount of post-Eocene erosion possible to $\sim 2.5$ (3) $\mathrm{km}$ and discount the possibility of large magnitude rapid cooling around 40 Ma permissible in the AFT thermal modelling of sample WG150/1 (Fig. 5d).

Samples WC147/2 and WC147/3, collected from outcrops further to the west (Fig. 2), also have Palaeogene AFT central cooling ages of $43 \pm 4 \mathrm{Ma}$ and $28 \pm 2 \mathrm{Ma}$, respectively. Thermal modelling of sample WC147/2 suggests relatively slow cooling during the Eocene and Oligocene epochs $\left(\sim 0.8^{\circ} \mathrm{C} \mathrm{Ma}^{-1}\right)$. This was followed by an acceleration in cooling $(\sim 4$ $20{ }^{\circ} \mathrm{C} \mathrm{Ma}^{-1}$ ) to near-surface temperatures that is most likely to have taken place during Early Miocene time (Fig. 5i). The early thermal history of this sample is poorly constrained, although the oldest modelled track age of 55 Ma provides some indication of when it began to pass through the partial annealing zone. The mean track length of sample WC147/3 is $14.14 \pm 0.21 \mu \mathrm{m}$, which indicates rapid cooling through the FT partial annealing zone, such that the measured AFT age approximates to the time of this cooling (down to temperatures $<\sim 60{ }^{\circ} \mathrm{C}$ ).

Sample WC49/1, from the Dakhovskiy Massif, yields AFT and ZFT ages of $127 \pm 5 \mathrm{Ma}$ and $272 \pm 29 \mathrm{Ma}$, respectively (Table 2). Stratigraphic relationships indicate that the massif was deformed and unroofed during latest Triassic to earliest Jurassic time and Bathonian to early Callovian time during early and middle Cimmerian orogenic events (Melnikov, Srabony'an \& Kokarev, 1994). The ZFT age determination, although not of high quality due to most grains having uncountable high track densities, is comparable with that from sample WG151/1. Combined with the stratigraphic evidence, this indicates average cooling of the western Greater Caucasus basement during PermoTriassic times of $\sim 3{ }^{\circ} \mathrm{C} \mathrm{Ma}^{-1}$ and implies $\sim 5(6.5) \mathrm{km}$ of unroofing of the massif during that time. The bestfit thermal model suggests that AFTs within sample WC49/1 were only partially annealed during heating to $\sim 60^{\circ} \mathrm{C}$ in the Late Jurassic-Early Cretaceous interval (explaining the sample's relatively old central age; Fig. 5e). Relatively rapid cooling to surface temperatures is modelled to have occurred sometime after Early Oligocene time.

\section{5.a.2. Flanks of the western Greater Caucasus}

Introduction. Four further bedrock samples were analysed from the flanks of the western Greater Caucasus (Table 1). On the southern flank of the range, a sample (WG137/1) was collected from metasediments of the Devonian to Triassic Dizi Series on the Tskhenis River, West Georgia. Another was collected from middle to upper Aptian sandstones along the Russian Black Sea coast between Sochi and Tuapse (sample WC39/2), and a third from Cenomanian sandstones on the Mzimta River (sample WC14/1; Fig. 2). A Lower Jurassic sandstone (sample WC120/1) was collected from the Mala Laba River on the northern flank of the range. 
AFT analysis was carried out on all four samples and ZFT analysis was also carried out on sample WG137/1. Insufficient track length data were available to model the cooling histories of these samples.

Results. Sample WG137/1 yields an extremely young AFT cooling central age $(2.5 \pm 0.6 \mathrm{Ma}$; Late Pliocene). If this age is assumed to record cooling due to exhumation it would imply rates of $\sim 1.2$ (1.6) $\mathrm{km} \mathrm{Ma}^{-1}$. However, taking into account the effect of advection, the corrected exhumation rate is likely to be closer to 0.9 (1.1) $\mathrm{km} \mathrm{Ma}^{-1}$ (Brandon in Ehlers et al. 2005). This is similar to the current erosion rates for the same structural zone obtained from the cosmogenic isotope analysis of river sands derived from the Inguri River catchment upstream of locality WG21 (sample WG21/1). This indicates an average lowering of the land surface by $60 \mathrm{~cm}$ over approximately the last 544 years which, if extrapolated to geological timescales, equates to a catchment-wide erosion rate of $\sim 1.1 \pm 0.3 \mathrm{~km} \mathrm{Ma}^{-1}$.

The zircon phase of sample WG137/1 yields a welldefined fission track age of $140 \pm 7 \mathrm{Ma}$. The 20 grains that were analysed form a single age population. The large difference between the ZFT and AFT ages for this sample signifies very recent cooling from temperatures above the apatite PAZ (that is, $>130^{\circ} \mathrm{C}$ ), but below the zircon PAZ $\left(\sim 200^{\circ} \mathrm{C}\right.$ for non-radiation-damaged zircon). This temperature range constrains the amount of recent exhumation to between $\sim 3-5 \mathrm{~km}$, based on a geothermal gradient of $\sim 40^{\circ} \mathrm{C} \mathrm{km}^{-1}$.

Samples WC39/2 and WC120/1 yield Aptian AFT central ages (117 \pm 8 and $118 \pm 12 \mathrm{Ma}$; Table 2). The fact that these central ages are either similar or younger than their depositional ages suggests that the AFTs within these samples have subsequently been partially to totally annealed. Sample WC39/2 contains apatites with a spread in ages that are not clearly linked to grain composition and suggests that some grains retain a strong provenance signal. Although only 22 track lengths were measured, a short mean track length of $12.4 \mu \mathrm{m}$ is consistent with an exit from the partial annealing zone more recently than the central age. The youngest, reset, grain ages at c. $50 \mathrm{Ma}$ (Fig. A1; available in online Appendix at http://journals.cambridge.org/geo) suggest that the onset of cooling occurred at or soon after this time. Sample WC120/1 displays a spread of AFT ages and a good correlation to grain composition consistent with a slow cooling history. The youngest grains at around $50 \mathrm{Ma}$ (Fig. A1) again point to the time of cooling below $\sim 60^{\circ} \mathrm{C}$ and departure from the partial annealing zone.

The apatites in sample WC14/1 come from an arkose that contains volcanic rock fragments and euhedral volcanic plagioclase feldspars. They yield a single age population and long track lengths $(14.4 \mu \mathrm{m})$, indicative of rapid cooling at $92 \pm 7 \mathrm{Ma}$. This is within error of its depositional age and is suggestive of a contemporaneous volcanic source for the apatite, consistent with the presence of pillow lavas of the same age that crop out $\sim 40 \mathrm{~km}$ to the northwest.

\section{5.a.3. Dziruli Massif}

Introduction. Three samples were analysed from the crystalline basement of the Dziruli Massif. The samples were collected in a $650 \mathrm{~m}$ vertical transect and range from Middle Jurassic (sample WG78b/1) to Palaeozoic in age (samples WG78c/1 and WC78e/1; Table 1).

Map and field data indicate that the Dziruli Massif underwent a phase of Middle Jurassic (probably syn-Bajocian) granitic intrusion (including sample WG78b/1) and subsequent cooling, with the intrusions being deformed and exhumed around the BathonianCallovian stage boundary as part of the middle Cimmerian orogeny (Kandelaki \& Kakhadze, 1956; this study). The massif was deeply weathered and peneplained prior to onlap during Early Cretaceous time before being exhumed again during the $\mathrm{Pa}$ laeogene period. This latter exhumation event is not well constrained, although stratigraphic relationships suggest it took place sometime between Middle Paleocene and middle Oligocene time. These events have been used to constrain the AFT thermal models discussed below.

Results. The samples yield AFT cooling central ages of between $171 \pm 11 \mathrm{Ma}$ and $115 \pm 6 \mathrm{Ma}$ (Bajocian to Aptian time; Table 2). Sample WG78b/1 has a ZFT age of $166 \pm 9 \mathrm{Ma}$, while samples WG78c/1 and WG78e/1 lacked sufficient zircon for analysis. The intrusion of Middle Jurassic granites will have perturbed the thermal structure of the region and locally elevated its geothermal gradient. Nevertheless, the coincidence of the ZFT cooling age in sample WG78b/1 and AFT cooling ages in samples WG78c/1 and WG78e/1 necessitates rapid cooling of all samples during the Middle Jurassic epoch. The oldest tracks recorded by the modelling suggest that cooling may have been initiated around $200 \mathrm{Ma}$ (Fig. 5).

The lowermost sample (sample WG78b/1) has the youngest AFT cooling age and a moderately short mean track length consistent with comparatively recent cooling from the partial annealing zone. Thermal modelling of the middle and upper samples provides a good fit with the analytical data (Fig. 5b, c). Both indicate that they have been at near-surface temperatures since Early Cretaceous time, consistent with their onlap by Valanginian-Hauterivian sediments. However, the samples do have different mean track lengths and modelled Jurassic cooling paths. Intermediate sample WG78c/1 is modelled to remain at upper crustal levels throughout the Jurassic period, despite evidence that the highest sample in the section cooled from around $120^{\circ} \mathrm{C}$ during that time. This is explained by differences in apatite chemistry, with the intermediate sample (WG78c/1) containing lower levels of chlorine (Table A1; available in online Appendix at http://journals.cambridge.org/geo) and 
therefore being less sensitive to annealing (Barbarand et al. 2003). The lowest sample is modelled to have left the partial annealing zone after the other samples, consistent with its AFT cooling age and stratigraphic position. Although thermal modelling does not provide as tight a fit with the analytical data, it does suggest a degree of burial reheating during the Cretaceous period, prior to cooling in latest Cretaceous to Eocene time (Fig. 5a).

\section{5.b. Oligo-Miocene sedimentary samples}

\section{5.b.1. Southern western Greater Caucasus}

\section{5.b.1.a. West Georgia}

Introduction. Uppermost Oligocene to lower Upper Miocene sediments from the southern flank of the western Greater Caucasus in West Georgia were collected from two river sections: Tskhenis (samples WG66c/2, WG67/8 and WG141/3) and Chanis (samples WG27/5, WG28c/1 and WG147/2) (Table 1; Fig. 2).

Results. Samples from the Tskhenis and Chanis rivers yield AFT central ages of between $169 \pm 16$ and $57 \pm 8 \mathrm{Ma}$ (Bajocian to Thanetian time). However, these samples contain mixed AFT age populations that comprise two age components: an older peak ranging between $192 \pm 12$ and $125 \pm 9 \mathrm{Ma}$ (Sinemurian to Barremian-Aptian time) and a younger age ranging between $59 \pm 9$ and $31 \pm 3 \mathrm{Ma}$ (Selandian to Rupelian time) (Table 2; Figs 6, A1; Figure A1 available in online Appendix at http://journals.cambridge.org/geo). These modes are all significantly older than the sample depositional ages and suggest that little if any post-depositional annealing has taken place. This interpretation is reinforced by the observation that apatite grain compositions, although highly variable, show no systematic relationship between composition and single grain age that is diagnostic of postdepositional annealing. The two age modes are thus thought to represent two different source area cooling histories within the evolving Caucasus. Insufficient track length data were collected from each mode to determine specific thermal histories, thus we can only rely on the relationship between the measured cooling ages and sample depositional ages to infer differences in source area exhumation rate.

Older apatite age populations. The principal AFT age modes within Cenozoic sedimentary rocks from West Georgia are $>100 \mathrm{Ma}$ older than their depositional age (Table 2; Fig. 6). This indicates that sediment was derived from a thermally stable source region within the Caucasus that had experienced only minor denudation during the Cenozoic era. The samples have cooling ages that are similar to those from the Dziruli Massif (Table 2).

The apatites from sample WG66c/2 from the Tskhenis River section in West Georgia yield a (U$\mathrm{Th} / \mathrm{He}$ as well as an AFT age date (Table 3). The euhedral apatites used for the helium analyses were largely associated with the older AFT age component

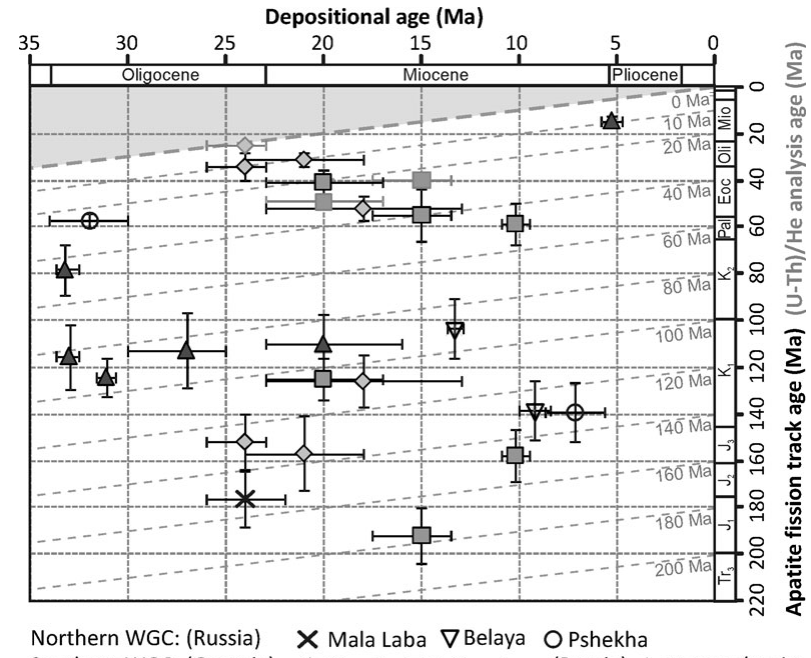

Southern WGC: (Georgia) $\diamond$ Chanis $\square$ Tskhenis (Russia) $\Delta$ Mzimta/Sochi

Figure 6. Time-lag plot between thermochronometric age and depositional age of sediments incorporated into Oligo-Miocene samples from the flanks of the western Greater Caucasus. See Figure 2 for the location of the sections from which the samples were collected. Note that two AFT age populations have been identified from the samples from the Chanis and Tskhenis rivers. The geological timescale is from Gradstein, Ogg \& Smith (2004).

and thus provide some additional insight into this age mode.

Sample WG66c/2 has an alpha ejection corrected $\left(\mathrm{F}_{\mathrm{T}}\right)$ helium age of $39.9 \pm 0.2 \mathrm{Ma}$. This suggests a minimum cooling rate of $\sim 40{ }^{\circ} \mathrm{C}$ in about $152 \mathrm{Ma}$ between Early Jurassic and Middle Eocene time $\left(\sim 0.3{ }^{\circ} \mathrm{C} \mathrm{Ma}^{-1}\right)$, followed by $40^{\circ} \mathrm{C}$ in about $25 \mathrm{Ma}$ between Middle Eocene time and the sample's Early Miocene depositional age $\left(\sim 1.6^{\circ} \mathrm{C} \mathrm{Ma}^{-1}\right)$. The euhedral nature of the apatites used in the helium analysis suggest that this is a reasonable assumption, although added complexities due to intermediate sediment storage may have affected the sample (see below).

Younger apatite age populations. The younger age modes are much closer to the sample depositional ages and, therefore, unless the apatites have a volcanic origin, they indicate a secondary source within the Caucasus that had experienced significant denudation sometime during Paleocene to Middle Miocene time (Table 2).

AFT ages generally increase with a decrease in the depositional age of the sediments from which they are derived (Fig. 6). This general trend may be the result of the chance sampling of apatites with differing thermal histories during changes in the catchments of the sediment supply systems that deposited the sandstones sampled in the Chanis and Tskhenis river sections. However, the trend would seem to be too systematic for this to be the case. If it is assumed that crust with the same thermal structure was eroded throughout, then the only way in which progressive erosion could generate cooling ages in detrital apatites that are progressively older up-section is if the cooling age structure had been inverted. It is highly unlikely that this could 


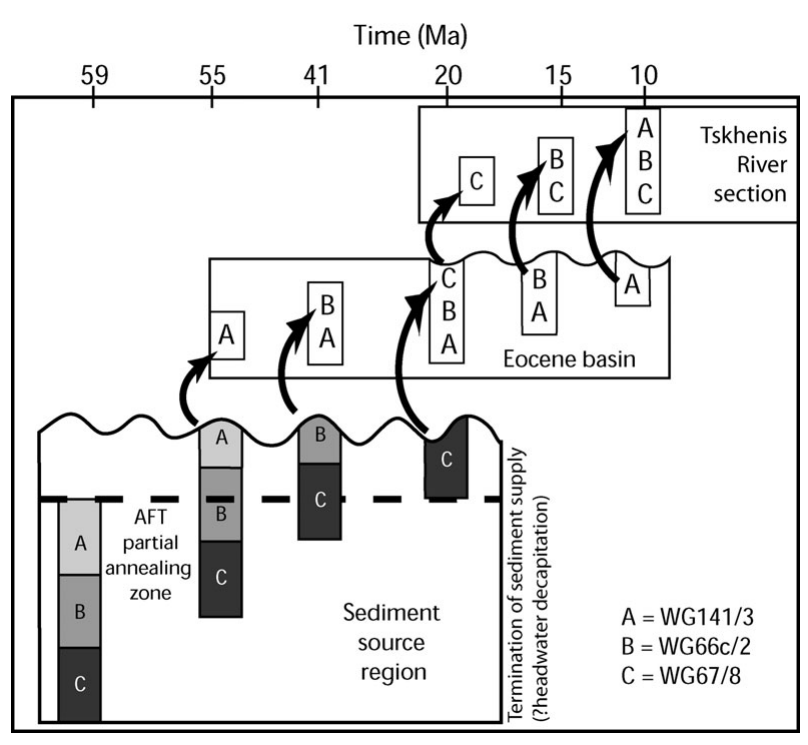

Figure 7. Model to explain the inverse relationship between depositional age and AFT age (see Fig. 6) for Miocene sediments from the Tskhenis River, West Georgian Greater Caucasus. This involves the inversion of the stratigraphy through an intermediate (most likely Eocene) sediment storage site.

be achieved tectonically, as this would involve the overturning of an unreasonably large crustal unit while not heating the base of the unit much above $60-90{ }^{\circ} \mathrm{C}$ to cause significant track annealing. Instead, this pattern is thought best achieved through the involvement of intermediate sediment storage prior to deposition in the sections sampled. This is illustrated schematically for samples from the Tskhenis River section in Figure 7. Significant amounts of reworked Eocene microfauna and flora within the sampled sections in West Georgia support this hypothesis.

The three oldest depositional samples in the region display the shortest lag times and are therefore likely to have been least affected by intermediate sediment storage. Sample WG67/8 from the Tskhenis River yields the shortest lag time $(20 \mathrm{Ma})$ for samples from this section (Fig. 6). Samples WG28c/1 and WG27/5 from the Chanis River section both display a 10 Ma time lag between their fission track cooling age and depositional age (Fig. 6), suggestive of steady state exhumation of the primary Caucasus source area averaging $10^{\circ} \mathrm{C} \mathrm{Ma}^{-1}$. Furthermore, the near contemporaneity of the depositional and (U-Th)/He age of sample WG28c/5 indicates that the source was affected by episodes of rapid cooling in Late Oligocene time, probably in excess of $20^{\circ} \mathrm{C} \mathrm{Ma}^{-1}$. As there is no clear relationship between apatite grain morphology and age it is unclear which FT source age modes the $(\mathrm{U}-\mathrm{Th}) / \mathrm{He}$ data relate to. Nevertheless, denudation must have been short lived and must not have exceeded $\sim 2 \mathrm{~km}$, otherwise the FT ages would also be expected to be much closer to the depositional age.

It is unclear which FT age mode the apatites used for the $(\mathrm{U}-\mathrm{Th}) / \mathrm{He}$ age determination of sample WG67/8 are related to. The alpha ejection corrected $\left(\mathrm{F}_{\mathrm{T}}\right)$ helium age of $49.5 \pm 0.1 \mathrm{Ma}$ is older than the younger FT age component (41 $\pm 5 \mathrm{Ma}$ ) (Tables 2, 3; Fig. 6). Therefore the apatites are either related to the older of the AFT age modes and display a similar cooling history to sample WG66c/2, or represent apatites from the younger age mode that have been affected by helium implantation from adjacent $\mathrm{U} / \mathrm{Th}$-bearing grains.

\section{5.b.1.b. Russia}

Introduction. Six samples from the Oligo-Miocene succession from the Mzimta River/Sochi region were analysed (WC7/1, WC92/8, WC94/3, WC99/3, $\mathrm{WC} 148 / 3$ and $\mathrm{WC149/3)}$ in order to test whether a similar exhumation signature to the West Georgian western Greater Caucasus was apparent in this region (Table 1; Fig. 2).

Results. Only single AFT age populations were identified in Oligo-Miocene sedimentary samples from the Russian western Greater Caucasus (Fig. A1). There is no apparent correlation between apatite chemistry and age, such that post-burial annealing is thought to have been minimal; intra-sample variations in AFT age are therefore likely to be dominated by variations in source area thermal history. Central ages range from $124 \pm 8$ to $15 \pm 2 \mathrm{Ma}$, with the majority of the samples having ages between 125 and $110 \mathrm{Ma}$ that are indicative of a relatively stable Caucasus sediment source (Table 2; Fig. 2). Evidence for Oligocene and younger exhumation is not apparent in the majority of the samples, although a lack of sufficient track lengths or apatite grains meant that it was not possible to model the thermal history of these samples or carry out lower temperature helium analysis.

Pontian sample WC148/3 does, however, display a young AFT age of $15 \pm 2 \mathrm{Ma}$ (Table 2). Apatites were extracted from a single granite clast within a conglomeratic unit and record the thermal history of the crystalline core of the western Greater Caucasus prior to $c$. $5 \mathrm{Ma}$. The granitic source material took a maximum of $9.5 \mathrm{Ma}$ to cool from $\sim 120^{\circ} \mathrm{C}$ and be eroded, resulting in similar average exhumation rates as Maykopian samples WG27/5 and WG28c/1 from West Georgia (Fig. 2).

\section{5.b.2. Northern western Greater Caucasus}

Introduction. Sandstones are rare within the outcrop stratigraphy on the northern side of the western Greater Caucasus. Five samples were analysed ranging from Early Oligocene to Meotian in age (Table 1; Fig. 2).

Results. Unroofing of the crystalline basement of the westernmost Russian Greater Caucasus by at least middle Oligocene time resulted in granitic clasts (among others) being incorporated into a conglomerate at the base of the Middle Maykopian Series in the Pshekha River. Such a clast (sample WC84/1) yields an AFT central age of $57 \pm 3 \mathrm{Ma}$, with only limited evidence for post-depositional annealing. Thermal modelling yields a moderate match with the analytical data and suggests that rapid cooling from around 
$\sim 50{ }^{\circ} \mathrm{C}$ was initiated some time from the Middle Eocene onwards.

The four other samples were taken from the Maykopian to Meotian succession on the northern side of the western Greater Caucasus. The central ages of all these samples range between $193 \pm 12$ and $138 \pm 12 \mathrm{Ma}$ (Table 2) and are similar to those within sediments from the southern side of the western Greater Caucasus. There is no correlation between apatite composition and age, suggesting limited postdepositional annealing, so that the AFT ages are likely to reflect the cooling age and relative thermal stability of the source material. Samples WC74/2 and WC123/1 represent single age populations, while in samples WC79/2 and WC128/1 the main apatite population age is around $165 \mathrm{Ma}$, although a number of younger grains are also present (Fig. A1, available in online Appendix at http://journals.cambridge.org/geo). These latter samples contain sufficient track lengths for these to be modelled (Fig. 5). Thermal modelling provides a close to moderate fit with the data and suggests that both samples were at upper crustal levels by the Late Jurassic epoch and underwent a protracted cooling history during Cretaceous and Cenozoic time (Fig. 5f, h).

\section{Towards an integrated exhumation history of the western Greater Caucasus}

The 39 new thermochronometric results detailed above cannot be expected to provide a complete picture of the complex geodynamic evolution of the western part of Europe's largest mountain belt. Nevertheless, when combined with other geological data a number of new insights are apparent.

\section{6.a. Permian-Early Cretaceous}

The Permian-Early Cretaceous evolution of the Greater Caucasus region is complex. Decreases in the intensity and/or changes in the style of deformation within rocks across major unconformities and the creation or changes in the geometry of discrete sedimentary packages have been used to define a series of orogenic and basin forming cycles (e.g. Nikishin et al. 2001), irrespective of whether the precise nature of these events and their driving mechanisms are fully understood (Saintot et al. 2006a,b).

ZFT analyses of samples from the central western Greater Caucasus yield Early-Middle Permian boundary and Middle Triassic cooling ages (samples WG151/1, WG153/1 and WC49/1; Table 2). When paired with the Early Oligocene AFT ages derived from the Mt Elbrus region (samples WG150/1and WG151/1), this indicates relatively slow average cooling rates of the order of $0.5^{\circ} \mathrm{C} \mathrm{Ma}^{-1}$ during much of Mesozoic and early Cenozoic time. Additional stratigraphic constraints, however, can refine this timetemperature pathway during the Mesozoic era in the northern part of the central western Greater Caucasus.
Here, onlap patterns indicate that the Dakhovskiy Massif was exhumed by earliest Jurassic time, so that cooling from the zircon PAZ to surface temperatures occurred during Middle Permian to end-Triassic time. This would imply $\sim 5(6.5) \mathrm{km}$ of unroofing of the massif during this time and an increased average cooling rate of around $3{ }^{\circ} \mathrm{C} \mathrm{Ma}^{-1}$. Clearly, cooling rates could have been even higher if much of the exhumation was restricted to particular episodes within the PermoTriassic epochs. For instance, detailed mapping of the Dakhovskiy region by Gaetani et al. (2005) suggests that much of the exhumation occurred during the late Olenekian to Anisian stages (latest Early to Early Middle Triassic time), a period of less than $10 \mathrm{Ma}$.

A regional unconformity between more deformed Bathonian and older strata and less deformed Callovian and younger sediments is developed along the flanks of the western Greater Caucasus (Fig. 3) and around the Dziruli and Loki massifs further south. This deformation event is termed the middle Cimmerian orogeny (marked MCO on Fig. 5). Best-fit thermal modelling is consistent with rapid cooling in a number of samples during this tectonic event (Fig. 5). Most AFT samples, however, collected from basement units or from clasts derived from these units, have central ages that are younger than this exhumation event. This implies either that the samples had not exited the PAZ for apatite during the Middle Jurassic epoch or that some degree of partial annealing had occurred during reburial in the Late Jurassic to Palaeogene epochs (as modelled for samples WG78b/1 and WC49/1; Fig. 5a, e). The latter must be the case for Lower Jurassic sediment sample WC120/1. In a similar thermochronometric study of the Crimea Mountains, Upper Triassic to Upper Jurassic sediments and volcanic rocks were shown to have passed back into the total annealing zone (TAZ) of apatite sometime between Early Cretaceous and Late Eocene time (Pánek et al. 2009).

Oligo-Miocene sedimentary samples derived from the central western Greater Caucasus typically display AFT ages that are significantly older than their depositional ages, with the majority of samples possessing Late Jurassic and Early Cretaceous cooling ages (Fig. 6). This again implies that the material later incorporated into these samples either cooled through the apatite PAZ during these epochs or that older tracks were partially annealed during Late Jurassic to Paleocene time.

\section{6.b. Late Cretaceous-Eocene}

Few samples provide thermochronometric evidence for cooling events during Late Cretaceous to Eocene time. Apart from sample WC14/1, which contains contemporaneous apatites, it is notable that only one sample yields apatites with a central age between 100 and $60 \mathrm{Ma}$ (Late Cretaceous to Middle Paleocene time). This may reflect the relative thermal stability of the region during this period, something apparent in the thermal modelling pathways of Figure 5. 
Six samples have latest Selandian to latest Lutetian AFT central or subpopulation ages (Table 2), and two $\mathrm{U}-\mathrm{Th} / \mathrm{He}$ analyses yield late Ypresian to earliest Bartonian ages (Table 3). Two samples contained sufficient tracks to be modelled. Of these, basement sample WC147/2 contains no evidence for anomalous cooling prior to the Miocene epoch (Fig. 5i). The other sample (WC84/1) comprises a granitic clast within an Upper Oligocene conglomerate on the Pshekha River that was probably derived from crystalline basement in the northwestern Greater Caucasus. Modelling suggests that this region underwent accelerated cooling sometime from Middle Eocene time (Fig. 5g), although it is possible that most of this occurred during Early Oligocene time, immediately prior to its exhumation, erosion and redeposition (see below).

Four of the six sedimentary samples from West Georgia in which AFT subpopulations have been identified yield a latest Selandian to latest Lutetian cooling age in the younger population (Table 2). Owing to the inverse relationship between their cooling and depositional ages noted earlier, samples WG66c/2, WG141/3 and WG147/2 at least must have undergone a period of intermediate sediment storage (most likely during Eocene time) prior to redeposition in the Miocene epoch (Fig. 7). Given their complex history of reworking, exhumation must have been much more rapid than indicated simply by the time lag between their cooling and depositional ages. The short mean track lengths of sediment samples WC39/2 and WC120/1 indicate that they exited the PAZ for apatite well after their central ages, with their youngest grain ages possibly indicating that this occurred during Early Eocene time.

A Middle Paleocene to middle Oligocene hiatus within a thin stratigraphic carapace to the Dziruli Massif suggests that the massif was at near-surface temperatures at this time. The best-fit thermal model of the lowermost Dziruli Massif sample (sample WG78b/1) is compatible with this cooling having been initiated in latest Cretaceous time (Fig. 5a). Exhumation of the Dziruli Massif may be the result of footwall uplift at the margins of the adjacent transtensional Adjara-Trialet basin or the more regional effects of the opening of the Eastern Black Sea and/or the closure of northern Neotethys.

\section{6.c. Oligo-Miocene to Present}

Best-fit thermal history models of basement samples from the crystalline core of the western Greater Caucasus all indicate Oligo-Miocene cooling events (Fig. 5d, e, i). The resolution of these events is not well constrained, although it would appear that cooling was most pronounced during the Miocene epoch.

Lag times between cooling ages and depositional ages of Oligo-Miocene sedimentary samples derived from the western Greater Caucasus are also instructive. As noted earlier, within many of the subpopulations an increasing lag time with decreasing depositional age suggests secondary storage and recycling. Neverthe- less, the minimum lag times for each subpopulation (generally the oldest depositional samples) provide some insights. The oldest (Early Oligocene) samples from the Mzimta and Pshekha rivers display AFT central age lag times in excess of $40 \mathrm{Ma}$ and $20 \mathrm{Ma}$, respectively (Fig. 6), although as noted above, thermal modelling of the latter sample (WC84/1) does indicate that the majority of this cooling occurred immediately prior to exhumation and deposition (Fig. 5g). Late Oligocene-Early Miocene samples from the Chanis River have AFT lag times of about $10 \mathrm{Ma}$, with an (U$\mathrm{Th} / \mathrm{He}$ age from the older of the samples indicating that this sample also underwent near-instantaneous cooling from around $40^{\circ} \mathrm{C}$ prior to deposition (Fig. 6). A granite clast from Pontian (uppermost Miocene) conglomerates from the Mzimta River region also yields an AFT lag time of about $10 \mathrm{Ma}$, this being equivalent to $\sim 0.25(0.33) \mathrm{km} \mathrm{Ma}^{-1}$.

In general, the AFT central ages of bedrock or modern sediment samples yield Oligocene or older cooling ages that are greater than the shortest lag times of the Oligo-Miocene sediment samples reviewed above. This indicates a possible slow-down in cooling rates during Plio-Pleistocene time and runs counter to climate-driven increases in denudation rate observed in the European Alps (Cederbom et al. 2004; Vernon et al. 2008) and elsewhere (Zhang, Molnar \& Downs, 2001; Molnar, 2004). The only exception to this is sample WG137/1 from the Tskhenis River that yields an extremely young AFT cooling central age $(2.5 \pm 0.6 \mathrm{Ma}$; Late Pliocene), equivalent to exhumation rates close to $0.9 \mathrm{~km} \mathrm{Ma}^{-1}$. This is very similar to the average current exhumation rates of a $2852 \mathrm{~km}^{2}$ area of the upper reaches of the Inguri River, upstream of the site from which cosmogenic sample WG21/1 was collected (Fig. 2). Old ZFT ages from WG137/1 suggest that the amount of exhumation for this sample was $\sim 3-5 \mathrm{~km}$, so that it is unlikely that these rates were initiated prior to the Pliocene epoch at the earliest. Combined ZFT and AFT cooling ages from samples from the crystalline core of the WCG close to Mt Elbrus indicate that Cenozoic exhumation here is unlikely to have exceeded $\sim 2.5 \mathrm{~km}$.

\section{Discussion}

Possibly the most striking finding of this study is the high rate of cooling/exhumation currently occurring in northwest Georgia (samples WG21/1 and WG137/1; Fig. 2). This is all the more surprising given the general lack of significant seismicity and low GPSderived convergence rates (Fig. 1). Due to uncertainties over the extent of this zone of rapid exhumation, two geodynamic scenarios are possible.

(1) The exhumation event may represent the 'piplike' expulsion of the largely Jurassic fill of the Greater Caucasus basin between the basement blocks of the Dziruli Massif (and its westward subsurface continuation) and the crystalline core of the western Greater Caucasus (Fig. 8). Despite the paucity of 
S

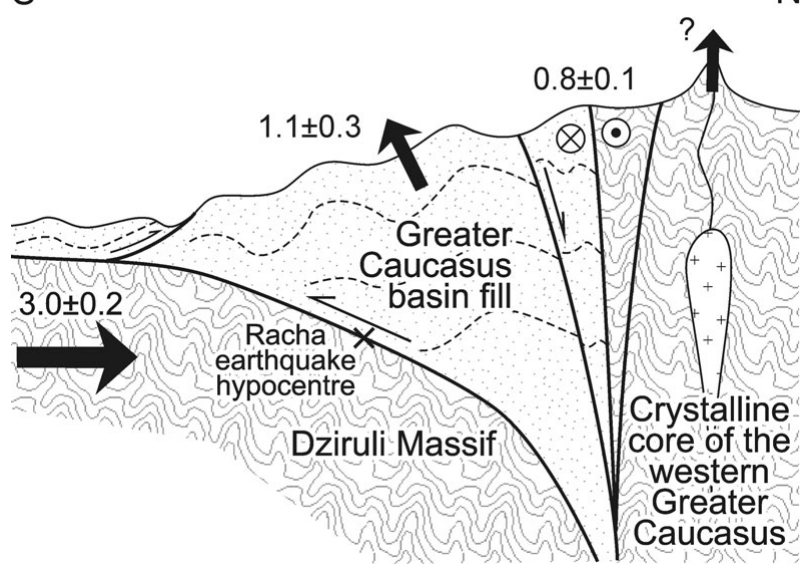

Figure 8. Cartoon showing a possible mechanism for the present-day rapid exhumation of the southern part of the western Greater Caucasus in West Georgia. Rates are in $\mathrm{mm} \mathrm{a}^{-1}$ $\left(\mathrm{km} \mathrm{Ma}^{-1}\right)$ and are derived from Reilinger et al. (2006) and this study.

significant seismicity within the study region, the largest instrumentally recorded earthquake in the Caucasus occurred in April 1991, immediately to the east of the area of known high exhumation (the Racha earthquake; $M_{s}=7.0 ;$ Fig. 2). Fault plane solution analysis of this event and its aftershocks indicate that it occurred on a thrust fault dipping NNE at $20-31^{\circ}$ either within the basement of the Dziruli Massif or between the massif and overlying Jurassic sediments (Triep et al. 1995). This may mark the base of this rapidly exhuming zone (Fig. 8). Due to political tensions, we have not been able to sample either further west (Abkhazia) or east (South Ossetia) to test whether similar rocks in these areas are undergoing equally rapid exhumation. Rates of exhumation are compatible with this being driven by active shortening.

(2) Rather than forming the backstop to exhumation, earlier thermochronometric studies suggest that the core of the western Greater Caucasus between Mt Elbrus and Mt Kazbeg is also undergoing rapid exhumation (Fig. 2). AFT analysis of crystalline samples in this region are ongoing to test this hypothesis. If correct, what is not clear is why this rapid exhumation does not occur to the west of MtElbrus. Král \& Gurbanov (1996) proposed that activity on a major NNE-SSW basement fault was responsible for the marked change in AFT ages that they recorded on either side of Mt Elbrus. They claimed that this structure could be traced to the region of Mineral'nyye Vody. However, there are no clear structure(s) apparent in the surface geology of the western Greater Caucasus that can be attributed to this feature or evidence for seismicity along this trend (Figs 1,2). As is the case further south, known GPSderived shortening rates could provide a plausible driving mechanism if high exhumation/uplift rates are present in the core of the Caucasus to the east of Mt Elbrus.

Lithospheric delamination of the root of the Greater Caucasus has been postulated as a cause for large-

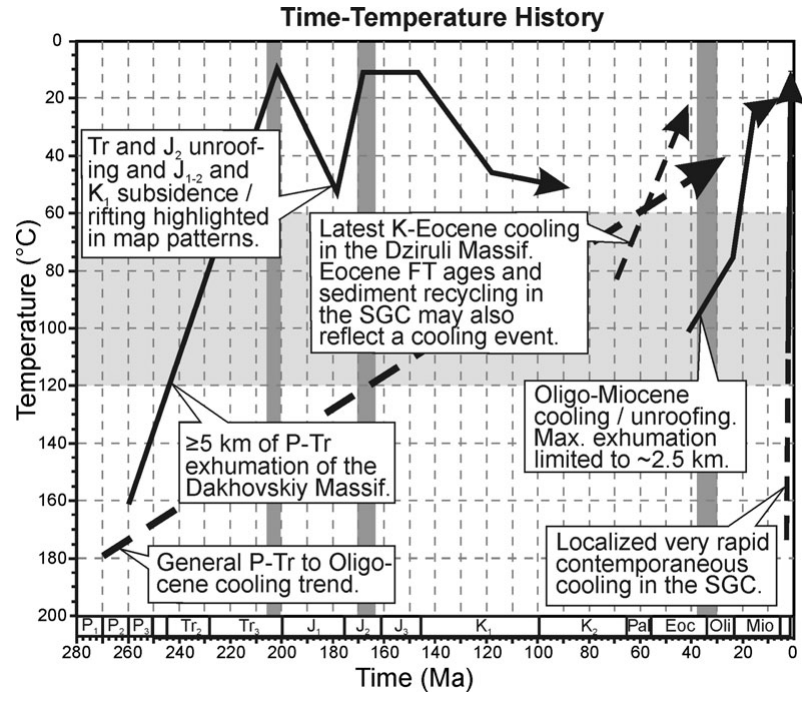

Figure 9. Schematic summary of generalized western Greater Caucasus cooling paths identified in this study. SGC - southern Greater Caucasus.

scale (aseismic) uplift (Ershov et al. 1999). However, tomographic data suggests that a negative velocity anomaly is only strongly developed beneath the Greater Caucasus at and to the east of Mt Kazbeg (Zor, 2008), east of the study region. Isostatic uplift in response to post-orogenic focused denudation (cf. Champagnac et al. 2007; Vernon, van der Beek \& Sinclair, 2009) is also discounted as a possible mechanism for the identified region of high exhumation due to the relatively small area affected and the high exhumation gradients necessary.

\section{Conclusions}

This thermochronometric study is consistent with previous work on the broad-scale tectonostratigraphic evolution of the western Greater Caucasus, with Cimmerian and Alpine cooling events being identified during Triassic to Middle Jurassic and Oligo-Miocene times, respectively (Fig. 9). Further work is needed to place the cooling and uplift of the Dziruli Massif within the complex Paleocene-Eocene tectonic evolution of the Tethysides and to test the significance of Eocene AFT cooling ages from samples situated along the southern margin of the western Greater Caucasus. The inverse relationship between AFT cooling age and depositional age of many of the Oligo-Miocene sediment samples, however, implies that some degree of Eocene erosion and intermediate sediment storage is likely.

The thermochronometric data are not sufficiently detailed to be able to better constrain time-temperature pathways during the Alpine transpressional evolution of the range, other than to confirm general OligoMiocene cooling and identify a number of pulsed events during this evolution. An increase in PlioPleistocene exhumation rates is not supported by the predominance of relatively old AFT ages obtained in this study. An exception to this is in northwest Georgia, where the region south of the crystalline core of the 
range has undergone rapid exhumation of $\sim 1 \mathrm{~km} \mathrm{Ma}^{-1}$ from possibly the Pliocene epoch onwards. Additional analyses are needed to test whether this is also the case within the core of the range east of Mt Elbrus.

In addition to constraining the timing of events, approximate amounts of cooling, and therefore exhumation, can be derived from the dataset. For instance, the ZFT age from a massif situated at the northern margin of the crystalline core of the western Greater Caucasus (that was unroofed by the end of the Triassic period) requires substantial amounts $(\sim 5 \mathrm{~km})$ of Permo-Triassic exhumation. In contrast, cooling ages from the core of the western Greater Caucasus to the west of Mt Elbrus restrict the overall amount of Cenozoic exhumation here to $\sim 2.5 \mathrm{~km}$ and reflect the relative thermal stability of the region since Late Jurassic to Early Cretaceous time.

Acknowledgements. This research would have been impossible without the field assistance of Lara Voronova and the support of CASP's industrial sponsors. Mike Simmons, Simon Inger, the late Robert Nadirashvili, Tanya Kalatch, Tanya Pinchuk, Tanya Mikerina, Vladimir Shishov, Viktor Sytnik and Li Guo are also thanked for their company and expertise in the field. We are grateful to Mirjam Schaller, Friedhelm von Blanckenburg and Peter Kubik for the cosmogenic analysis of sample WG21/1 and Robin Clayton for the helium analysis of samples WG28c/5, WG66c/2 and WG67/8. Prof. Poporadze (Tbilisi) provided samples WG150/1, WG151/1 and WG153/1 from his own collection and the use of this material is gratefully acknowledged. Robert Scott and Hugh Sinclair are thanked for their helpful comments on the manuscript, as are Aline Saintot and a further anonymous reviewer. This is Cambridge Earth Sciences contribution esc. 1323.

\section{References}

Adamia, S. A., Gamkrelidze, I. P., Zakariadze, G. S. \& LORDKIPANIDZE, M. B. 1974. Adjaria-Trialeti trough and problem of the Black Sea origin. Geotektonica 1, 78-94 (in Russian).

AdAMIA, S. A., LORDKIPANIDZE, M. B. \& ZAKARIADZE, G. S. 1977. Evolution of an active continental margin as exemplified by the Alpine history of the Caucasus. Tectonophysics 40, 183-99.

Afanasenkov, A. P., Nikishin, A. M. \& OBukhov, A. N. 2007. Eastern Black Sea Basin: Geological Structure and Hydrocarbon Potential. Moscow: Science World, 172 pp. (in Russian).

Allen, M. B., Vincent, S. J., Alsop, G. I., Ismail-ZADEH, A. \& FLECKER, R. 2003. Late Cenozoic deformation in the South Caspian region: effects of a rigid basement block within a collision zone. Tectonophysics 366, 22339.

Apaydin, B., Menlikli, C. T., SipahioĞlu, Ö. \& Aydemir, V. 2009. Tertiary sedimentary fill of the Western Black Sea basin. 2nd International Symposium on the Geology of the Black Sea Region, Abstracts (ed. M. Dalkılıç), p. 23. Ankara, Turkey: MTA.

ArTeMJeV, M. E. 1980. On the relation between Cenozoic tectonic movements and isostatic disturbances. In Earth Rheology, Isostasy and Eustasy (ed. N.-A. Mörner), pp. 357-69. Chichester: Wiley.

AvdeEV, B. \& NiEMI, N. A. 2008. Constraints on the rates and timing of exhumation of the Greater Caucasus from low-temperature thermochronology. Eos Transactions $A G U$ 89(53). Fall Meeting Supplement, Abstract T33C2075.

Barbarand, J., CARTer, A., WoOd, I. \& Hurford, T. 2003. Compositional and structural control of fissiontrack annealing in apatite. Chemical Geology 198(1-2), 107-37.

Belousov, T. P. \& EnMan, S. V. 1999. Morphostructural maps and tectonic movements of the Stavropol high since Quaternary and during the recent stage of development. Geomorphology 4, 56-70 (in Russian).

BoztuĞ, D., JONCHEERE, R., WAGNER, G. A. \& YeĞINGIL, Z. 2004. Slow Senonian and fast Palaeocene-Early Eocene uplift of the granitoids in the Central Eastern Pontides, Turkey: apatite fission-track results. Tectonophysics 382(3-4), 213-28.

Brown, R. W. \& Summerfield, M. A. 1997. Some uncertainties in the derivation of rates of denudation from thermochronologic data. Earth Surface Processes and Landforms 22, 239-48.

Cederbom, C. E., Sinclair, H. D., Schlunegger, F. \& RAHN, M. K. 2004. Climate-induced rebound and exhumation of the European Alps. Geology 32, 709-12.

Champagnac, J. D., Molnar, P., Anderson, R. S., Sue, C. \& Delacou, B. 2007. Quaternary erosion-induced isostatic rebound in the western Alps. Geology 35, 1958.

Deramond, J., Souquet, P., Fondecave-Wallez, M.-J. \& SPECHT, M. 1993. Relationships between thrust tectonics and sequence stratigraphy surfaces in foredeeps: model from the Pyrenees (Cretaceous-Eocene, France, Spain). In Tectonics and Seismic Sequence Stratigraphy (eds G. D. Williams \& A. Dobb), pp. 193-219. Geological Society of London, Special Publication no. 71.

Dercourt, J., GAetani, M., VRIELyncK, B., BARrier, E., BiJu-Duval, B., Brunet, M. F., CADET, J. P., CRASQuin, S. \& Sandulescu, M. (eds) 2000. Atlas Peri-Tethys, Palaeogeographical Maps. Paris: CCGM, CGMW, 269 pp.

DileK, Y. \& AltunKaYNAK, Ş. 2009. Geochemical and temporal evolution of Cenozoic magmatism in western Turkey: mantle response to collision, slab break-off, and lithosphere tearing in an orogenic belt. In Collision and Collapse at the Africa-Arabia-Eurasia Subduction Zone (eds D. J. J. Van Hinsbergen, D. J. J. Edwards \& R. Govers), pp. 213-33. Geological Society of London, Special Publication no. 311.

Dixon, J. E. \& Robertson, A. H. F. (eds) 1984. The Geological Evolution of the Eastern Mediterranean. Geological Society of London, Special Publication no. 17,824 pp.

Donelick, R. A., O’Sullivan, P. B. \& Ketcham, R. A. 2005. Apatite fission-track analysis. In Low-temperature Thermochronology: Techniques, Interpretations and Applications (eds P. W. Reiner \& T. A. Ehlers), pp. 49-94. Reviews in Mineralogy and Geochemistry no. 58.

Ehlers, T. A., Chaudhri, T., Kumar, S., Fuller, C. W., Willet, S. D., Ketcham, R. A., Brandon, M. T., Belton, D. X., Kohn, B. P., Gleadow, A. J. W., DUNAI, T. J. \& FU, F. Q. 2005. Computational tools for low-temperature thermochronometric interpretation. In Low-Temperature Thermochronology: Techniques, Interpretations, and Applications (eds P. W. Reiners \& T. A. Ehlers), pp. 589-622. Chantilly, VA: Reviews in Mineralogy and Geochemistry no. 58 . 
Ershov, A. V., Brunet, M. F., Korotaev, M. V., Nikishin, A. M. \& Bolotov, S. N. 1999. Late Cenozoic burial history and dynamics of the Northern Caucasus molasse basin: implications for foreland basin modelling. Tectonophysics 313, 219-41.

Farley, K. A., Wolf, R. A. \& Silver, L. T. 1996. The effects of long alpha-stopping distances on (U-Th)/He ages. Geochimica et Cosmochimica Acta 60, 4223-9.

Gaetani, M., Garzanti, E., Polino, R., Kiricko, Y., Korsakhov, S., Cirilli, S., NicORA, A., RetTori, R., LARGHI, C. \& PAlliani, R. B. 2005. Stratigraphic evidence for Cimmerian events in NW Caucasus (Russia). Bulletin Société géologique de France 176, 283-99.

Galbraith, R. F. \& Laslett, G. M. 1993. Statistical models for mixed fission track ages. Nuclear Tracks and Radiation Measurement 21, 459-70.

Gallagher, K., Brown, R. W. \& Johnson, C. J. 1998. Geological applications of fission track analysis. Annual Review of Earth and Planetary Sciences 26, 51972.

Gautheron, C. E., TAssan-Got, L. \& FArLey, K. A. 2006. (U-Th)/Ne chronometry. Earth and Planetary Science Letters 243, 520-35.

GAZIS, C. A., LANPHERE, M., TAYLOR, H. P. \& GURBANOV, A. $1995 .{ }^{40} \mathrm{Ar} /{ }^{39} \mathrm{Ar}$ and ${ }^{18} \mathrm{O} /{ }^{16} \mathrm{O}$ studies of the Chegem ash-flow caldera and the Eldjurta Granite: cooling of two late Pliocene igneous bodies in the Greater Caucasus Mountains, Russia. Earth and Planetary Science Letters 134, 377-91.

GENÇ, Ş. C. \& YILMAZ, Y. 1997. An example of postcollisional magmatism in Northwestern Anatolia: the Kizderbent Volcanics (Armutlu peninsula, Turkey). Turkish Journal of Earth Sciences 6, 33-42.

GolonKA, J. 2004. Plate tectonic evolution of the southern margin of Eurasia in the Mesozoic and Cenozoic. Tectonophysics 381, 235-73.

Gradstein, F. M., OgG, J. G. \& Smith, A. G. 2004. A Geologic Time Scale 2004. Cambridge: Cambridge University Press, 589 pp.

GrÜn, R., TANi, A., GURBanov, A., Koshchug, D., Williams, I. \& BRAUN, J. 1999. A new method for the estimation of cooling and denudation rates using paramagnetic centres in quartz: a case study on the Eldzhurtinskiy Granite, Caucasus. Journal of Geophysical Research 104, 17531-49.

GÜNEY, H., DEMIRER, A., SiPAHIOĞLU, Ö \& AYdEMIR, V. 2009. The structural framework of the Andrusov Ridge. In 2nd International Symposium on the Geology of the Black Sea Region (ed. M. Dalkılıç), pp. 84-5. Ankara, Turkey: MTA.

Gunnell, Y., Calvet, M., Brichau, S., Carter, A., Aguilar, J.-P. \& ZEYEN, H. 2009. Low long-term erosion rates in high-energy mountain belts: insights from thermo- and biochronology in the Eastern Pyrenees. Earth and Planetary Science Letters 278, 208-18.

Hanel, M., Gurbanov, A. G. \& LiPPOLT, H. J. 1992. Age and genesis of granitoids from the Main-Range and Bechasyn zones of the western Great Caucasus. Neues Jahrbuch für Mineralogie, Monatshefte 1992(12), 52944.

Hanel, M., Lippolt, H. J., Kober, B., Gurbanov, A. G. \& BorsuK, A. M. 1993. On the Early Paleozoic age of metagranodiorites in the Main Range Zone of the Greater Caucasus. Petrology 1, 487-98.

Hess, J. C., LipPolt, H. J., GuRBANOV, A. G. \& MichalsKi, I. 1993. The cooling history of the late Pliocene Eldzhurtinskiy granite (Caucasus, Russia) and the thermochronological potential of grain-size/age relationships. Earth and Planetary Science Letters 117, 393-406.

Hossack, J. 2004. The tectonic evolution of the Black Sea. In Continental Tectonics: discussion meeting in memory of the life and work of Mike Coward (eds A. Beach, R. Butler, R. Graham, R. Knipe, K. McClay, A. Ries \& S. Stewart). Geological Society London, Abstracts.

Hovius, N., VAldes, P., Weissel, J., Allen, M. B. \& IsmailZADEH, A. 2001. The time lag between mountain building and precipitation-driven erosion in the eastern Greater Caucasus. Earth System Processes - Global Meeting. Edinburgh: Geological Society of America, Abstracts.

HuRforD, A. J. 1990. Standardization of fission track dating calibration: recommendation by the Fission Track Working Group of the IUGS subcommission on geochronology. Chemical Geology 80, 177-8.

HURFORD, A. J. \& GREEN, P. F. 1983. The zeta age calibration of fission track dating. Isotope Geoscience 1, 285-317.

JACKSON, J. 1992. Partitioning of strike-slip and convergent motion between Eurasia and Arabia in Eastern Turkey and the Caucasus. Journal of Geophysical Research 97(B9), 12471-9.

Jackson, J., Priestley, K., Allen, M. \& Berberian, M. 2002. Active tectonics of the South Caspian Basin. Geophysics Journal International 148, 214-45.

Jones, R. W. \& Simmons, M. D. 1997. A review of the stratigraphy of Eastern Paratethys (OligoceneHolocene), with particular emphasis on the Black Sea. In Regional and Petroleum Geology of the Black Sea and Surrounding Region (ed. A. G. Robinson), pp. 39-52. AAPG Memoir no. 68.

KAMLADZE, G. \& KACHKACHSHVILI, M. 1976. Summary of geological and geophysical materials on Abkhazia and Megrelia. Abkhazian geological expedition. Ministry of Petroleum Industry, "Gruzneft"” Union (in Russian), $214 \mathrm{pp}$.

KandelaKi, N. A. \& KaKhadze, I. R. 1956. Geological map of the USSR, Caucasus series sheet K-38-XIV, 1:200,000. Moscow: Ministry of Geology.

Kazmin, V. G., Schreider, A. A. \& BulycheV, A. A. 2000. Early stages of evolution of the Black Sea. In Tectonics and Magmatism in Turkey and the Surrounding Area (eds E. Bozkurt, J. A. Winchester \& J. D. A. Piper), pp. 235-49. Geological Society of London, Special Publication no. 173.

Keskin, M., Genç, S. C. \& TÜYsüZ, O. 2008. Petrology and geochemistry of post-collisional Middle Eocene volcanic units in North-Central Turkey: evidence for magma generation by slab breakoff following the closure of the Northern Neotethys Ocean. Lithos 104, 267 305.

Khain, V. E. \& Milanovsky, E. E. 1963. Structure tectonique du Caucase d'après les données modernes. Memoires de la Société géologique de France 2, 663 703.

KhriachtchevsKaia, O., Stovba, S. M. \& Stephenson, R. 2010. Cretaceous-Neogene tectonic evolution of the northern margin of the Black Sea from seismic reflection data and tectonic subsidence analysis. In Sedimentary Basin Tectonics from the Black Sea and Caucasus to the Arabian Platform (eds M. Sosson, N. Kaymakci, R. Stephenson, F. Bergerat \& V. Starostenko). Geological Society of London, Special Publication, no. 340.

KRÁL, J. \& GURBANOV, A. G. 1996. Apatite fission track data from the Great Caucasus pre-Alpine basement. Chemie Der Erde - Geochemistry 56(2), 177-92. 
Kubik, P. W., Ivy-Ochs, S., Masarik, J., Frank, M. \& SCHLUCHTER, C. $1998 .{ }^{10} \mathrm{Be}$ and ${ }^{26} \mathrm{Al}$ production rates deduced from an instantaneous event within the dendrocalibration curve, the landslide of Kofels, Otz Valley, Austria. Earth and Planetary Science Letters 161, 23141.

LAVRishcheV, V. A., PrUtSkiY, N. I. \& SEMEnov, V. M. 2002. National Geological Map of the Russian Federation, Caucasus series sheet K-37-V (Krasnar Polyana), 1:200,000. Moscow: St Petersberg Cartographic Enterprise of VSEGEI.

LavrishcheV, V. A., Semenov, V. M., Andreev, N. M. \& GorshKov, A. S. 2000. National Geological Map of the Russian Federation, Caucasus series sheet K-37-IV (Sochi), 1:200,000. Moscow: St. Petersberg cartographic enterprise of VSEGEI.

LOZAR, F. \& POLINO, R. 1997. Early Cenozoic uprising of the Great Caucasus revealed by reworked calcareous nannofossils. EUG 9, 23-27 mars 1997, Strasbourg. Terra Nova 9 (Abstract supplement no. 1), 141.

MaslyaeV, G. A. 1990. Formation of the Cenozoic structure of the Cis-Caucasus. Geotectonics 24, 321-8.

Matoshko, A. V., Gozhik, P. F. \& Semenenko, V. 2009. Late Cenozoic fluvial development within the Sea of Azov and Black Sea coastal plains. Global and Planetary Change 68, 270-87.

Melnikov, Y. V., Srabony'An, M. K. \& KoKarev, A. D. 1994. Geological map of the USSR, Caucasus series sheet L37-XXXV, 1:200,000. St. Petersberg: St. Petersberg cartographic enterprise of VSEGEI.

Meulenkamp, J. E. \& Sissingh, W. 2003. Tertiary palaeogeography and tectonostratigraphic evolution of the Northern and Southern Peri-Tethys platforms and the intermediate domains of the African-Eurasian convergent plate boundary zone. Palaeogeography $\mathrm{Pa}$ laeoclimatology Palaeoecology 196, 209-28.

Mikhailov, V. O., Panina, L. V., Polino, R., KoroNOVsKy, N. V., KiseleVA, E. A., KlaVdieva, N. V. \& SMOLYANINOVA, E. I. 1999. Evolution of the North Caucasus foredeep: constraints based on the analysis of subsidence curves. Tectonophysics 307, 361-79.

Mikhailov, V. O., Smolyaninova, E. I. \& Sebrier, M. 2002. Numerical modeling of neotectonic movements and the state of stress in the North Caucasus foredeep. Tectonics 21, 1025, doi:10.1029/2002TC001379, 14 pp.

Milanovsky, E. E. 1991. Geology of the USSR, Part 3. Moscow: Moscow University Press, 272 pp. (in Russian).

MiLANOVSKY, E. E. 2008. Origin and development of ideas on Pliocene and Quaternary glaciations in northern and eastern Europe, Iceland, Caucasus and Siberia. In History of Geomorphology and Quaternary Geology (eds R. H. Grapes, D. Oldroyd \& A. Grigelis), pp. 87115. Geological Society of London, Special Publication no. 301.

Molnar, P. 2004. Late Cenozoic increase in accumulation rates of terrestrial sediment: how might climate change have affected erosion rates? Annual Review of Earth and Planetary Sciences 32, 67-89.

Muratov, M. V., Arkhipov, I. V. \& Uspenskaya, Y. A. 1984. Structural evolution of the Crimean Mountains and comparison with the Western Caucasus and the Eastern Balkan Ranges. International Geology Review 26, 1259-66.

NAYLOR, M. \& SinclaiR, H. D. 2007. Punctuated thrust deformation in the context of doubly vergent thrust wedges: implications for the localization of uplift and exhumation. Geology 35, 559-62.
NeSmeYanov, S. A. 1995. Pleistocene deformation of Black Sea terraces along the Caucasus coast. Geotectonics 29, 259-69.

Nikishin, A. M., Cloetingh, S., Bolotov, S. N., BARABOSHKIN, E. Y., KopaEVICH, L. F., NAZAREVICH, B. P., PANOV, D. I., BRUNET, M.-F., ERShOV, A. V., ILINA, V. V., Kosova, S. S. \& Stephenson, R. A. $1998 a$. Scythian Platform: chronostratigraphy and polyphase stages of tectonic history. In Peri-Tethys Memoir 3: Stratigraphy and Evolution of Peri-Tethyan Platforms (eds S. Crasquin-Soleau \& E. Barrier), pp. 15162. Paris: Mémoires du Muséum national d'Histoire naturelle no. 177.

Nikishin, A. M., Cloetingh, S., Brunet, M.-F., StephenSon, R. A., Bolotov, S. N. \& Ershov, A. V. $1998 b$. Scythian Platform, Caucasus and Black Sea region: Mesozoic-Cenozoic tectonic history and dynamics. In Peri-Tethys Memoir 3: Stratigraphy and Evolution of Peri-Tethyan Platforms (eds S. Crasquin-Soleau \& E. Barrier), pp. 163-76. Mémoires du Muséum national d'Histoire Naturelle no. 177.

Nikishin, A. M., KorotaeV, M. V., ERshov, A. V. \& BRUnet, M.-F. 2003. The Black Sea basin: tectonic history and Neogene-Quaternary rapid subsidence modelling. Sedimentary Geology 156, 149-68.

Nikishin, A. M., ZIEgler, P. A., PANOV, D. I., NAZAREVICH, B. P., Brunet, M.-F., StePhenson, R. A., Bolotov, S. N., KorotaeV, M. V. \& TiKhomirov, P. L. 2001. Mesozoic and Cainozoic evolution of the Scythian PlatformBlack Sea-Caucasus domain. In Peri-Tethys Memoir 6: Peri-Tethyan Rift/Wrench Basins and Passive Margins (eds P. A. Ziegler, W. Cavazza, A. H. F. Robertson \& S. Crasquin-Soleau), pp. 295-346. Mémoires du Muséum national d'Histoire Naturelle no. 186.

OKAY, A. I. \& ŞAHINTÜRK, O. 1997. Geology of the Eastern Pontides. In Regional and Petroleum Geology of the Black Sea and Surrounding Region (ed. A. G. Robinson), pp. 291-311. Tulsa, Oklahoma: AAPG Memoir no. 68.

OKAY, A. I., TANSEL, I. \& TÜYSÜZ, O. 2001. Obduction, subduction and collision as reflected in the Upper Cretaceous-Lower Eocene sedimentary record of western Turkey. Geological Magazine 138, 117-42.

OKAY, A. I. \& TÜYSÜZ, O. 1999. Tethyan sutures of northern Turkey. In The Mediterranean Basins: Tertiary Extension within the Alpine Orogen (eds B. Durand, L. Jolivet, F. Horváth \& M. Séranne), pp. 475-515. Geological Society of London, Special Publication no. 156

OKAY, A. I., ZATTIN, M. \& CAVAZZA, W. 2010. Apatite fission-track data for the Miocene Arabia-Eurasia collision. Geology 38, 35-8.

PÁNEK, T., DANIŠÍK, M., HRADECKÝ, J. \& FRISCH, W. 2009. Morpho-tectonic evolution of the Crimean mountains (Ukraine) as constrained by apatite fission track data. Terra Nova 21, 271-8.

Philip, H., Cisternas, A., GVishiani, A. \& GorshKov, A. 1989. The Caucasus: an actual example of the initial stages of continental collision. Tectonophysics 161, 121.

Popov, S. V., Shcherba, I. G., Ilyina, L. B., NEVESSAKAYA, L. A., PARAMONOVA, N. P., KHONDKARIAN, S. O. \& MAGYAR, I. 2006. Late Miocene to Pliocene palaeogeography of the Paratethys and its relation to the Mediterranean. Palaeogeography Palaeoclimatology Palaeoecology 238, 91-106.

ReILINGer, R., MCClusky, S., VERnANT, P., LAWRENCE, S., ERgintaV, S., CAKMAK, R., OzEnER, H., Kadirov, F., Guliev, I., Stepanyan, R., NADARIYA, M., Hahubia, 
G., Mahmoud, S., Sakr, K., ArRajehi, A., ParaDISSIS, D., Al-AYdrus, A., PrilePIN, M., GuSEVA, T., Evren, E., Dmitrotsa, A., Filikov, S. V., Gomez, F., AL-GHAZZI, R. \& KARAM, G. 2006. GPS constraints on continental deformation in the Africa-Arabia-Eurasia continental collision zone and implications for the dynamics of plate interactions. Journal of Geophysical Research 111, B05411, 26 pp.

Rice, S. P., Robertson, A. H. F. \& Ustä̈mer, T. 2006. Late Cretaceous-Early Cenozoic tectonic evolution of the Eurasian active margin in the Central and Eastern Pontides, northern Turkey. In Tectonic Development of the Eastern Mediterranean Region (eds A. H. F. Robertson \& D. Mountrakis), pp. 413-45. Geological Society of London, Special Publication no. 260.

Robertson, A. H. F., PARlaK, O. \& Ustä̈mer, T. 2009. Melange genesis and ophiolite emplacement related to subduction of the northern margin of the TaurideAnatolide continent, central and western Turkey. In Collision and Collapse at the Africa-Arabia-Eurasia Subduction Zone (eds D. J. J. Van Hinsbergen, D. J. J. Edwards \& R. Govers), pp. 9-66. Geological Society of London, Special Publication no. 311.

Robinson, A. G., Rudat, J. H., BANKS, C. J. \& Wiles, R. L. F. 1996. Petroleum geology of the Black Sea. Marine and Petroleum Geology 13, 195-223.

SAINTOT, A. \& ANGELIER, J. 2002. Tectonic paleostress fields and structural evolution of the NW-Caucasus foldand-thrust belt from Late Cretaceous to Quaternary. Tectonophysics 357, 1-31.

Saintot, A., Brunet, M.-F., Yakovlev, F., SÉbrier, M., STEPHENSON, R., ERShOV, A., ChAlOT-PrAT, F. \& MCCANN, T. 2006a. The Mesozoic-Cenozoic tectonic evolution of the Greater Caucasus. In European Lithosphere Dynamics (eds D. Gee \& R. Stephenson), pp. 27789. Geological Society of London, Memoir no. 32.

Saintot, A., Stephenson, R., Stovba, S., Brunet, M.-F., Yegorova, T. \& StAROSTENKO, V. 2006 $b$. The evolution of the southern margin of the Eastern Europe (Eastern European and Scythian platforms) from the latest Precambrian-Early Palaeozoic to the Early Cretaceous. In European Lithosphere Dynamics (eds D. Gee \& R. Stephenson), pp. 481-505. Geological Society of London, Memoir no. 32.

ŞENGÖR, A. M. C. 1987. Tectonics of the Tethysides: orogenic collage development in a collisional setting. Annual Review of Earth and Planetary Sciences 15, 213-44.

ŞENGÖR, A. M. C. \& NATAL'IN, B. A. 1996. Paleotectonics of Asia: fragments of a synthesis. In The Tectonic Evolution of Asia (eds Yin An \& T. M. Harrison), pp. 486-640. Cambridge: Cambridge University Press.

ŞENGÖR, A. M. C. \& YILMAZ, Y. 1981. Tethyan evolution of Turkey: a plate tectonic approach. Tectonophysics $\mathbf{7 5}$, 181-241.

Somin, M. L. 2000. Structure of axial zones in the Central Caucasus. Doklady Earth Sciences 375, 1371-4.

Somin, M. L., Kotov, A. B., SAL'NikOVA, E. B., LEVCHENKOV, O. A., PIS'MENNYI, A. N. \& YAKOVleva, S. Z. 2006. Paleozoic rocks in intrastructure of the metamorphic core, the Greater Caucasus Main Range Zone. Stratigraphy and Geological Correlation 14, 47585.

Somin, M. L., LePeKhINA, E. N. \& Konilov, A. N. 2007. Age of the high-temperature gneiss core of the Central Caucasus. Doklady Akademii Nauk 414, 1-5 (in Russian).

Somin, M. L., Potapenko, Y. Y. \& SMUl'skaya, A. I. 2009. Chuchkhur xenoliths and tectonic position of
Middle Paleozoic volcano-sedimentary sequences in the Peredovoi Range, Northern Caucasus. Doklady Earth Sciences 428, 1097-9.

Spadini, G. S., Robinson, A. G. \& Cloetingh, S. 1996. Western versus Eastern Black Sea tectonic evolution: pre-rift lithospheric controls on basin formation. Tectonophysics 266, 139-54.

SukhareV, G. M., TARANuKha, Y. K. \& Vlasov, S. P. 1964. Geothermal features of Caucasus oil and gas deposits. International Geology Review 6, 1541-56.

Treloar, P. J., Mayringer, F., Finger, F., Gerdes, A. \& SHENGALIA, D. 2009. New age data from the Dzirula Massif, Georgia: implications for Variscan evolution of the Caucasus. In 2nd International Symposium on the Geology of the Black Sea Region, Abstracts (ed. M. Dalkılıç), pp. 204-5. Ankara, Turkey: MTA.

TrieP, E. G., ABERS, G. A., LERNER-LAM, A. L., MishatKIN, V., ZAKHARCHENKO, N. \& StAROVOIT, O. 1995. Active thrust fault of the Greater Caucasus: the April 29, 1991, Racha earthquake sequence and its tectonic implications. Journal of Geophysical Research 100(B3), 4011-33.

Vasiliev, I., Krijgsman, W., Stoica, M. \& Langereis, C. G. 2005. Mio-Pliocene magnetostratigraphy in the southern Carpathian foredeep and MediterraneanParatethys correlations. Terra Nova 17, 376-84.

VERNON, A. J., VAN DER BEeK, P. A. \& SinClair, H. D. 2009. Spatial correlation between long-term exhumation rates and present-day forcing parameters in the western European Alps. Geology 37, 859-62.

VERNON, A. J., VAN DER BEEK, P. A., SINClAIR, H. D. \& RAHN, M. K. 2008. Increase in late Neogene denudation of the European Alps confirmed by analysis of a fissiontrack thermochronology database. Earth and Planetary Science Letters 270, 316-29.

Vincent, S. J., Allen, M. B., Ismail-Zadeh, A. D., Flecker, R., Foland, K. A. \& Simmons, M. D. 2005. Insights from the Talysh of Azerbaijan into the Paleogene evolution of the South Caspian region. Geological Society of America Bulletin 117, 1513-33.

Vincent, S. J., Morton, A. C., CARTer, A., GibBS, S. \& BARABADZE, T. G. 2007. Oligocene uplift of the Western Greater Caucasus; an effect of initial Arabia-Eurasia collision. Terra Nova 19, 160-6.

Von Blanckenburg, F., BelshaW, N. S. \& O’Nions, R. K. 1996. Separation of ${ }^{9} \mathrm{Be}$ and cosmogenic ${ }^{10} \mathrm{Be}$ from environmental materials and SIMS isotope dilution analysis. Chemical Geology 129, 93-9.

YilmaZ, A., AdAmia, S., ChabUKiANi, A., ChKHOtUA, T., ERdoĞAN, K., Tuzcu, S. \& KarabiYIKoĞLU, M. F. 2000. Structural correlation of the southern Transcaucasus (Georgia)-eastern Pontides (Turkey). In Tectonics and Magmatism in Turkey and the Surrounding Area (eds E. Bozkurt, J. A. Winchester \& J. D. A. Piper), pp. 171-82. Geological Society of London, Special Publication no. 173.

YilmaZ, Y., TÜYsüz, O., YıĞıtbaş, E., CAN GenÇ, S. \& ŞENGÖR, A. M. C. 1997. Geology and tectonic evolution of the Pontides. In Regional and Petroleum Geology of the Black Sea and Surrounding Region (ed. A. G. Robinson), pp. 183-226. AAPG Memoir no. 68.

ZAKARIADZE, G. S., DILEK, Y., ADAMIA, S. A., OBERHÄNSLI, R. E., KARPENKO, S. F., BAZYLEV, B. A. \& SOLOV'EVA, N. 2007. Geochemistry and geochronology of the Neoproterozoic Pan-African Transcaucasian Massif (Republic of Georgia) and implications for island arc evolution of the late Precambrian Arabian-Nubian Shield. Gondwana Research 11, 92-108. 
Zhang, P., Molnar, P. \& Downs, W. R. 2001. Increased sedimentation rates and grain sizes 2-4 Myr ago due to the influence of climate change on erosion rates. Nature 410, 891-7.

Zonenshain, L. P., KuZMin, M. I. \& NATAPOV, L. M. 1990. Geology of the USSR: A Plate Tectonic Syn- thesis. Washington: American Geophysical Union 21, $242 \mathrm{pp}$.

ZoR, E. 2008. Tomographic evidence of slab detachment beneath eastern Turkey and the Caucasus. Geophysical Journal International 175, 127382.

\title{
ERRAT UM
}

\section{The exhumation of the western Greater Caucasus: thermochronometric study - Erratum}

\author{
STEPHEN J. VINCENT, ANDREW CARTER, VLADIMIR A. LAVRISHCHEV, \\ SAMUEL P. RICE, TEIMURAZ G. BARABADZE \& NEILS HOVIUS
}

In Vincent et al. (2010) the boxed key shown on Figure 2 includes the following definition:

$$
\begin{aligned}
\text { Symbol diameter } & =\text { AFT age or lag time }(\mathrm{Ma}) \\
& \approx \text { erosion rate }\left(\mathrm{km} \mathrm{Ma}^{-1}\right)
\end{aligned}
$$

The symbol diameter is inversely proportional to the AFT age or time lag and proportional to the erosion rate; the definition should therefore read:
Symbol diameter $\propto 1$ / AFT age or lag time (Ma) $\propto$ erosion rate $\left(\mathrm{km} \mathrm{Ma}^{-1}\right)$

(see scale bars below)

\section{Reference}

Vincent, S. J., CARTER, A., LAVRishChEV, V. A., Rice, S. P., BARABADZE, T. G. \& Hovius, N. (2010) The exhumation of the western Greater Caucasus: thermochronometric study. Geological Magazine, published online 05 May 2010. doi: 10.1017/S0016756810000257. 